\title{
The Possibilities of Open-Cast Mining in Landscape Parks in Poland-A Case Study
}

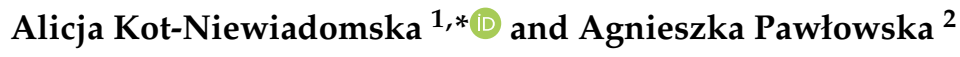 \\ 1 Mineral and Energy Economy Research Institute Polish Academy of Science, Provision of Mineral Policy, \\ Wybickiego 7A, 31-261 Kraków, Poland \\ 2 "Czatkowice" Limestone Mine, Czatkowice Dolne 78, 32-065 Krzeszowice, Poland; \\ a.pawlowska@czatkowice.com.pl \\ * Correspondence: a.kn@min-pan.krakow.pl
}

Received: 13 September 2020; Accepted: 13 October 2020; Published: 15 October 2020

\begin{abstract}
Landscape parks are one of the most important tools for nature conservation in Europe. Cultural landscape protection, coupled in particular with rural tradition of land use plays a very important role. A common feature of these popular protected areas is the fact that they are established legally, in accordance with the principle of sustainable development. Activities carried out in the landscape parks are not entirely subservient to nature conservation. This makes them different from national parks and natural reserves. In Poland, landscape parks together with their buffer zones cover more than $13 \%$ of the country's territory, which frequently causes conflicts among mining entrepreneurs and limits their activities. Mining in landscape parks in Poland is not forbidden by domestic law; however, detailed guidelines in this respect are determined by the assembly of a given province. Additionally, the process of applying for an extraction licence could be burdened with the threat of social protests, which may result in extending it by many years, and because of which a project may fail to be completed. Optimal solutions to these obstacles are already proposed by "Czatkowice" Limestone Mine (Małopolska Province). This case study presents an efficient practice of a smooth and effective decision-making process of obtaining a new mining licence in a landscape park. It also outlines certain aspects of the social licence to operate (SLO) as well as some appropriate methods of acting in complicated environments and spatial conditions.
\end{abstract}

Keywords: mining; nature conservation; Poland

\section{Introduction}

Nature conservation in Europe and other parts of the world, is usually accomplished within designated protected areas. The history of their creation across the globe most likely reaches back to the end of 18th [1,2] and the first half of 19th century in Europe [3] and began with forms of strict protection-nature reserves and then the national parks [4]. The history of conservation is generally tied to the industrial age, as a kind of backlash against exploitation of uncontrolled industrial growth and unfettered capitalism of the age [5]. However, every time, principles for any kind of protection are determined in dedicated legislation and, depending on a form adopted, impose various restrictions on specific kinds of stakeholders. Essentially, the highest protection regime concerns national parks and nature reserves, lower-yet still high-forms that can be jointly described as "landscape parks" (names differ from country to country, see Section 2 for details).

Without doubt, the effective nature conservation is nowadays an essential component of sustainable development of societies but the need to acquire mineral resources [6] from their primary sources, in other words, mineral deposits are equally important. Although nature conservation is deeply rooted in the law and regulated by legislation in virtually all European countries, Poland included [7], 
the protection of deposits, which are one of the environmental resources, still needs to be clarified; Poland is no exception. The offered domestic legal regulations are too general to allow for the effective protection of mineral deposits with mineral reserves (also unexploited) and mineral deposits with mineral resources. Moreover, the legislations are only addressed for mineral deposits with mineral resources (prospective areas are not included). Also essential for effective deposit safeguarding is development of valorisation methodology of mineral deposits in order to identify deposits of significant importance for the national and regional economy. The above elements are not defined in Poland, which determines the non-effective deposit safeguarding process. The lack of guidelines for the protection of deposits and, at the same time, multiple forms of nature conservation with their high coverage across the country give rise to many conflicts. Moreover, the Polish mining industry is known for its methods of extraction. All rock minerals and lignite in Poland are extracted using the open-cast method (with no prospects to develop underground mining). Only hard coal, ores ( $\mathrm{Cu}-\mathrm{Ag}, \mathrm{Zn}-\mathrm{Pb})$ and salt are mined underground, while sulphur is mined using the method of underground melting. Therefore, open-cast mining is responsible for providing approximately 40 different minerals [8] vital for proper functioning of the Polish economy. This is possible through the operation of more than 6000 mining plants, extracting approximately 350 million tonnes of rock minerals and more than 61 million tonnes of lignite per year [9], which employ hundreds of thousands of workers. Mining areas designated for deposits extracted using the open-cast mining method in total cover more than $870 \mathrm{~km}^{2}$, including more than $350 \mathrm{~km}^{2}$ for lignite deposits. It accounts for a mere $0.27 \%$ of the country's area. Nonetheless, the non-renewable nature of deposits, their affinity to specific geological structures (and, thus, their specific location) and undisputable role in economic development accompanied by the need or, in fact, the necessity of their extraction, cause natural conflicts between functions and directions of use of a specific piece of land [10]. Without a doubt, the fact that more than a third of the country is covered by spatial forms of nature conservation is conducive to such conflicts. In this context, taking into account deficiencies in Polish spatial policy, the lack of protection for mineral deposits and often complex environmental, social and spatial conditions, the ability to use mineral deposits in a sustainable manner constitutes a challenge to the mining sector.

The "Czatkowice" Limestone Mine (further: "CLM") located in the Lesser Poland Province (see: Section 4), a part of TAURON Group, is one of the examples. From its beginnings, this mine had to function under complex external conditions in which nature conservation, taking various forms in close proximity of the mine, has been determining its operations from many years. This mine, demonstrating good practice in conducting mining operations that take the environmental and social conditions into account, has become the subject-matter of this paper whose aim is to present possibilities of conducting mining operations in landscape parks in Poland.

The works which have been published so far discuss the problem of accessing deposits located within protected areas usually only from a regional perspective (e.g., [11-15]), and additionally, in recent years putting emphasis mainly on the sites classified as Natura 2000 (e.g., [16-22]). Environmental constraints on mineral deposit extraction, including nature protection, have also become a crucial issue while considering their valorisation aimed at designating the deposits which must be protected (e.g., [23]). In this context the existing nature protection areas (landscape parks in particular) are considered a significant obstacle in the way of mining development. As a consequence, in the valorisation process the value of a given deposit - in view of the environmental criterion-is reduced and beginning extraction is put at risk. The goal of the article, however, is to demonstrate that the deposit location within the boundaries of a landscape park does not exclude the possibility of its usage. Nevertheless, it requires entrepreneurs to undertake specific measures, directed particularly towards not only environmental issues, but most of all to social aspects. Obtaining the support and acceptance of the local community is often of paramount importance for further steps.

The following article is an expansion of a study which was presented in 2019 during the 3rd International Conference on Sustainable Energy and Environmental Development [10]. The research was extended to include international and historical background, and the quantitative analyses 
supplemented with a division into landscape parks and their buffer zones. From the standpoint of economic activity (which may concern mining) it is very important, with limitations in buffer zones often being less strict. An important part of the study is detailed quantitative analysis illustrating the current scale of the issue in Poland and presenting the subject matter based on a marked (selected) case study. The team authors were extended to include a representative of the analyzed mine which allowed for an extensive and reliable analysis of the factors determining the company's success. The "Czatkowice" Limestone Mine was also determined as a case study in a MinLand Project. The project required the example presenting the land use management process at every stage of mining activity (from prospection to reclamation).

\section{Materials and Methods}

The article presents a detailed investigation of possibilities of open-cast mining within landscape parks in Poland. The study was preceded by providing a general characterisation of forms of natural protection such as landscape parks in other European countries, the starting point of which were the results of the international project entitled "Europe's Nature, Regional and Landscape Parks" [24]. These results enabled the correlation of Polish landscape parks with analogous forms of nature conservation in Europe Reviewing the available legal acts which remain in force, the authors could additionally specify conditions related to mining activities

Regarding the current situation in Poland, the starting point of analysis was a detailed description of legal conditions based on current acts in effect. Among them, the Act of 16 April 2004 on Nature Conservation [25] served as the basis. Additionally, it was necessary to scrutinise several acts pertaining directly to the subject matter of the article, namely: The Act of 27 April 2001 Environmental Law [26], The Act of 24 April 2015 on the Amendment of Certain Acts in Relation to the Strengthening of Landscape Protection Tools [27], The Act of 3 October 2008 on Sharing Information about the Environment and its Protection, Public Participation in Environmental Protection and Environmental Impact Assessment [28] together with Regulation of the Council of Ministers of 10 September 2019 on projects likely to have a significant impact on the environment [29].

In the next step, the number and location of the Polish landscape parks is provided on the basis of the Central Register of Nature Conservation Forms [30] run by the General Directorate for Environmental Protection. The Central Geological Database [31] as well as the balance of mineral resources deposits in Poland [9] (both developed by Polish Geological Institute-National Research Institute) became, in turn, the source of a quantitative review of deposits. The authors subsequently correlated the spatial data, which allowed them to select 13 raw materials groups. Among them, the deposits exploited within the boundaries of landscape parks as well as those lying in their buffer zones were indicated. Within the resulting division, the authors pointed out the number of deposits together with the volume of extracting particular minerals.

The essential part of the work is devoted to the chosen case study. In fact, "Czatkowice" Limestone Mine remains one of the best Polish examples of sustainable open-cast mining activity in extremely complex environmental conditions. Taking into account its very short time of obtaining of mining licence, its territorial scope (area of mining area and mining land) and exceptionally long timeframe as well as the scale of production, the mine can be considered an almost perfect example of how mining development may go hand in hand with respect for nature protection. Here it should be emphasized that like many natural resource sectors, the mining industry is under considerable pressure in recent years to improve its environmental and social performance. The financial and reputational costs (e.g., financial support for local community or community investment projects) of mining in areas that are environmentally or socially vulnerable are high for both natural resource companies and the companies that insure and finance them. Simultaneously competition for land use, and related conflicts of interest, and restrictions on land access present increasing challenges to all forms of mining and extractive activities. Mines in certain areas (e.g., landscape/natural/regional parks) may need to accommodate competing interests related to environmental protection and tourism. Although, the area 
of land required by mining activities is commonly relatively small, and release of potentially harmful emissions from modern mines has been substantially minimized, that the main task for the next few years is to strike a balance between economic growth and nature conservation as increasing numbers of conflicts arise between different stakeholders. In this context the analyzed mine should be the template of best practice guidelines for other mining entrepreneurs.

\section{Results}

\subsection{Landscape Parks in Europe}

The history of landscape parks in Europe reaches back to the 1950s and 1960s [32], which were the period of rising industrialisation and intensification of land use by agriculture as well as housing, transportation and industry. This phenomenon, apart from affecting the environment, also had a negative impact on society. With this background, the idea of designating 25 protected areas in the form of a landscape parks was born in Germany in 1956 [33] in order to preserve their natural values so that local communities might benefit from them for recreational and leisure purposes [34]. The first landscape park in Germany was already established this way in 1957 [35]. At the same time, the first protected area of this type was also created in Great Britain [36] and, in the 1960s, in France that would protect its rural areas in the first place [37]. In subsequent years landscape parks appeared in other countries, including Poland. It is a relatively new idea, dating a dozen years back, for Switzerland and Norway [38] from which the concept of landscape parks spread to other Scandinavian countries such as Denmark and Iceland, where it is being developed [39].

Despite significant historical differences as well as administrative and legal conditions that can be observed in individual countries, duties and goals assigned for landscape parks are similar across the whole of Europe. In many cases they are a key element of the nature conservation system.

Currently, there are more than 900 protected areas in Europe, which correspond with existing landscape parks in Poland. All of them were constituted under the law of a given country. Depending on the country they may be called "nature parks" (Germany, Austria, Belgium, Bulgaria, Croatia, Denmark, Hungary, Portugal) or "regional parks" (Italy, Lithuania, Norway, Great Britain, Croatia, Scotland), more rarely "landscape parks" (Poland), "protected landscape areas" (Czech Republic, Latvia, Slovakia) or even "areas of outstanding natural beauty" -AONB (Great Britain). Their total area takes up more than $8 \%$ of the European Union, Switzerland and Norway [38] but in particular countries it may be from $2 \%$ (Bulgaria) [40] up to as much as $28 \%$ of the area (Germany) [41]. According to classification of the International Union for Conservation of Nature (IUCN), they fall within category $\mathrm{V}$ of nature conservation: protected landscapes [42,43]. In Europe they represent exceptional areas particularly rich in natural and cultural heritage, in other words, such areas where interaction of nature and people has over time created vital ecological, biological, cultural and landscape value [24]. As opposed to, for example, North America, the landscape parks do not only protect structures and bounds of nature. In Europe, the element of cultural landscape protection, particularly bound with rural tradition of land use plays a very important role [37].

In every country, landscape parks have their own organisational structure responsible for the implementation of their short-(5 years), medium-(10-12 years) or long-term (20 years) objectives [38]. These objectives are specified in the so-called "Park Charter" or a plan of its protection (the "Management Plan" in the UK), prepared by administrative bodies of a specific level, always in cooperation with a local government. In Germany, Austria and the United Kingdom it is the local government that plays a key role in designating and establishing landscape parks (the so-called German model). France, followed by Luxembourg, Belgium and Switzerland, chose another-combined-model based on close cooperation between a local and the national government in order to specify directions of the development and functioning of an individual park (the so-called French model) [44]. In Italy, Spain and Poland, competences to designate, appoint and specify directions for landscape parks development lie solely with governments on a regional level. 
In terms of responsibilities, landscape parks across Europe share their general goals, which are: biodiversity protection, sustainable development of rural areas, ecological education and education for sustainable development as well as sustainable tourism and recreation. Specific goals in individual countries may differ and change over the years [38]. Each time, however, a role assigned to them is extremely difficult as they have to combine nature conservation with the sustainable social and economic development in order to sustain and also to improve the condition of natural and cultural heritage of a specific region.

A common feature of this-popular in Europe-form of nature conservation undoubtedly is an opportunity for economic development and the provision of services as long as it is done in accordance with the principle of sustainable development and preservation of biological and landscape diversity. The agricultural policy should comply with standards of environmental protection and strive for the conservation of the cultural landscape and its multifunctionality. In transport, the development of railway and public transport should be given priority while spatial development should strive for the rational use of space and conservation of natural values of the environment [37].

According to guidelines of the World Conservation Congress that was held in Amman in 2000, the exploration and extraction of minerals in the 5th category of nature conservation (in which landscape parks fall) are only admissible providing that the form and scope of proposed mining project activities indicate for the consistency of the project with the goals of an individual protected area. Moreover, granting permission to carry out exploration, prospecting and mining works requires an environment impact assessment for a project and the approval of the environmental impact assessment report by a competent body and group of stakeholders in the form of social consultations [45].

However, these are only general recommendations and the detailed conditions are regulated by state (e.g., Poland, Sweden, Slovakia) or federal (regional) law (e.g., Austria, Germany, Italy). Many European countries allow the possibility of extraction in landscape parks. It is clear that a balance must be maintained and the environment carefully managed. It is for this reason that quarrying in the landscape park is carefully controlled and before permission is given for further extraction, high priority is given to safeguarding the landscape.

In Sweden all exploration activities are prohibited in national parks. Exploration may, however, after approval be allowed in all other types of protected areas, including landscape parks [46]. Serbian law indicates that in the area which represents a protected space of nature, an area of cultural-historical and construction significance, a tourist-recreational area, a source of special importance for regional water supply and the like, performance of geological exploration and mining of mineral reserves may only be approved under the conditions which, in accordance with special law, are issued by authorities and organizations competent in spatial development, nature and environment protection, cultural heritage and other authorities and organizations in charge of the specific area relating to protected natural spaces [47]. Furthermore, German law allows mining activity but with the reservation that any destruction of parts or components of landscapes in the course of mining for natural resources shall be avoided. Lasting damage to the balance of nature shall be prevented. Any adverse effects on nature and landscapes which inevitably result from the exploration and extraction of natural resources and from soil deposits shall be compensated for by recreating the original landscape or by relandscaping areas modelled after nature [48]. France also presents a similar attitude [49]. Portugal is also in the group of countries that enable mining activities in local natural parks. One example is the Natural Park of Serras de Aire e Candeeiros (NPSAC). In 2010, a new land use plan and respective regulatory framework was implemented for the NPSAC. Recognising the social and economic importance of the extractive activity within the natural park, this new management plan established general rules for the mining industry aimed at its compatibility with environmental protection and valorisation of natural resources. In view of those policy guidelines, a set of five Areas of Specific Intervention (ASI) for the quarrying development of ornamental stones was defined at the regional level in the new Natural Park Land Use Plan [50]. According to the legal Portuguese land management framework, the aforementioned ASIs should be subjected to detailed 
land use planning at the municipal level aimed at the establishment of compatibility measures between rational mining activity, the environmental restoration of degraded areas and the conservation of existing natural values [50].

The full suite of rural businesses commonly present within AONBs in England is mixed and varied. The high quality landscape within AONBs, however, provides increased opportunities for businesses centred on tourism, recreation, outdoor education and creative activities when compared to other areas. AONB partnerships therefore work closely with those that have a direct influence on the resource (among others extractive industry) and those whose business model depends upon the sustainable stewardship of the resource. The extractive industry functions within the boundaries of AONB, but compared to other branches of the economy (e.g., transport, agriculture, creative services) its importance is less [51].

Economic and other activities and projects which do not pose a threat to its essential features and roles are permitted in nature and regional parks in Croatia [38]. Exploration and exploitation of mineral resources shall be carried out in such a manner as to conserve landscape values of the space to the highest degree possible. Harmful effects on a landscape likely to be caused by exploitation of mineral resources shall be avoided by selecting the most favourable site, type and scope of the activity planned [52]. Economic activity within these parks in Latvia must be carried out in accordance with national and European Union legislation on the protection of species and habitats [38].

Italy, Germany and Austria define framework legislation of landscape parks on regional (federal) levels. As a result, the "world" of regional parks is varied, although there is general uniformity, thorough analysis requires further studies of suitable acts.

\subsection{Landscape Parks in Poland}

\subsubsection{Legal Conditions-Outline}

Landscape parks (further: "LP") are one of the most important parts of the national system for protection of nature and landscape in Poland which, according to the Act of 16 April 2004 on Nature Conservation [25], consists of seven forms: national parks, nature reserves, landscape parks, protected landscape areas, Natura 2000 sites, sites of ecological interest as well as natural and landscape complexes (Table 1, Figure 1). It is worth noting that the last two are forms of individual conservation and pertain to specific natural formations. If other surface forms with the top, high and middle protection regimes are considered, more than $30 \%$ of the area of Poland is covered by legally established nature conservation forms (Figure 1).

Table 1. Spatial forms of nature conservation in Poland (based on: $[25,30])$.

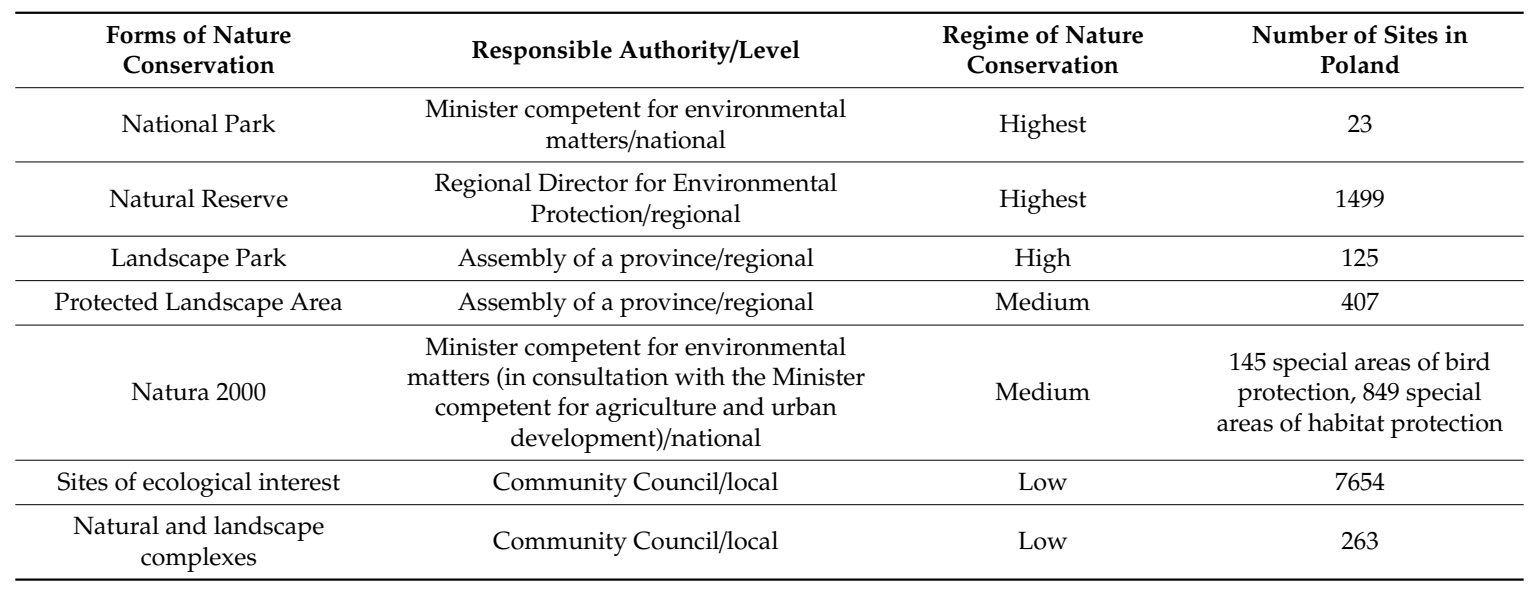




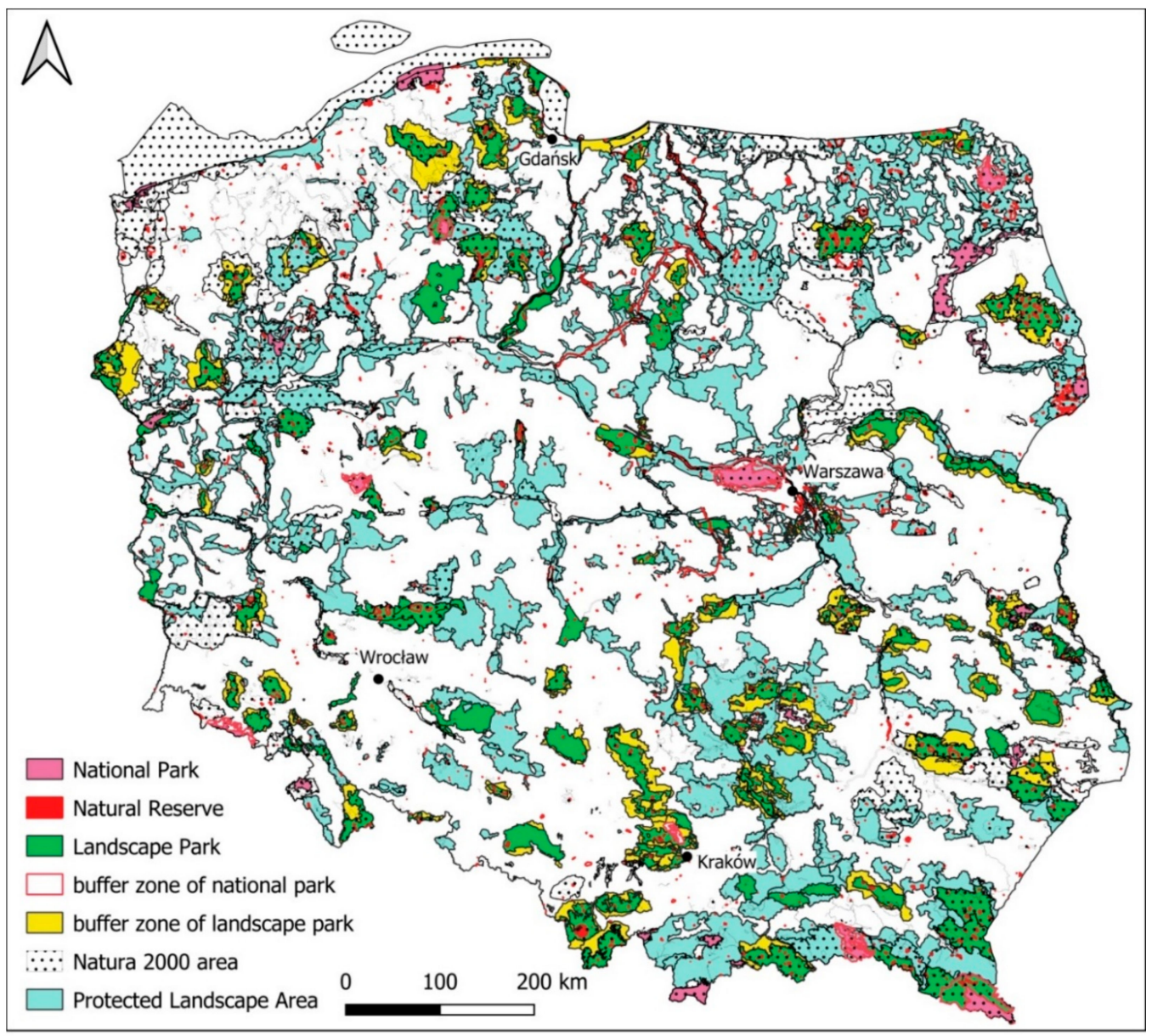

Figure 1. The most important spatial forms of nature conservation in Poland (based on: [30]).

Each of the mentioned forms plays a different role in the Polish nature conservation programme and serves different purposes, hence it is characterised by an individual conservation regime and scope of use limitations. Only covered by strict protection means that the economic activity, mining included, is prohibited. In Poland, the prohibition refers only to national parks and nature reserves.

Current issues related to establishing and operating of landscape parks in Poland are governed by the Act of 16 April 2004 on Nature Conservation [25]. Article 16 (in Section 1) of the act states as follows: "A landscape park comprises an area protected due to its natural, historical and cultural qualities as well as landscape values in order to preserve and popularise these qualities in conditions of the sustainable development". Strengthening of legal regime of landscape parks was imposed by the Act of 24 April 2015 on the Amendment of Certain Laws in Connection with Strengthening of Landscape Conservation Tools (the so-called "landscape act") [27]. Its main objective was to ensure consistency of Polish law with the European Landscape Convention [53] through strengthening of legal tools for landscape conservation [54]. This act introduces the legal definition of "landscape" and defines landscape values as "natural, cultural, historical, aesthetic and visual qualities of an area together with terrain relief, formations and parts of nature related to these qualities as well as civilisation elements, shaped by the forces of nature or human activity" [27]. This definition clearly points at the meaning and importance of cultural elements in landscape conservation.

In practical terms, landscape parks have clearly defined borders and have areas from several to tens of thousands of hectares. Their borders delineate sites of valuable landscape bearing few traces of transformation, combined with high natural value, equal at times to values of national parks [55]. Similar to sites with near-natural landscapes, parks also comprise cultural landscapes shaped by several centuries-long traditions. If several parks of limited area appear in close proximity to one 
another or within the borders of a single province, they are joined to form a complex of landscape parks. Optionally, in accordance with the Nature Conservation Act, in areas adjoining a landscape park a buffer zone may be created so that its natural values are even more protected [56]. The way of space management within the buffer zone and its size are determined on a case-by-case basis by an authority forming an individual park with its buffer zone. The act [25], in this scope, provides no specific guidelines whatsoever.

In its subsequent articles, the act defines a number of optional bans that may be imposed in a landscape park, whereas the authority in charge of such bans is the assembly of a province. The very same authority, by way of local legislation, in other words, a resolution of the assembly of a province, determines the name of an LP, its size, lines of borders and the buffer zone (if it was created), special purposes of the protection as well as prohibitions specific to a given landscape park or a part thereof, selected from among prohibitions indicated in Article 17 of the Nature Conservation Act [25]. This way, the competencies to govern an LP in Poland are assigned to regional level authorities, while local level authorities (the community council) have advisory functions as far as the draft resolution establishing an individual LP and the conservation plan are concerned. As a matter of fact, a community council may issue a negative opinion when the adoption of such a resolution would limit the community's developmental opportunities resulting from arrangements laid down in local planning documents (the study of conditions and directions of spatial development or the local zoning plan) to an extent disproportionate to values the landscape park is expected to protect.

For each individual LP, the act introduces an obligation to create a respective plan of protection determining goals for nature conservation as well as natural, social and economic conditions of their implementation. Moreover, the "landscape act" [27] as part of creating the park protection plan, among other things, obliges the provincial local government to prepare a landscape audit with an aim to identify, characterise and evaluate the landscapes. The landscape audits will be a basis for designating landscapes of priority that are particularly valuable for the society due to their natural, cultural, historical, architectural, urban, rural or aesthetic and visual qualities which, as such, require the observance or specification of rules and principles aimed at the conservation of these qualities [57]. An example of a priority landscape may be a viewing point. Assemblies of a province may delineate landscape protection zones within the boundaries of priority landscapes designated in an audit, for which the preservation of highest landscape values is required. This way, the highest level of protection is granted to such landscape park areas which were considered the priority landscapes.

A protection plan is drawn up for a period of 20 years [25]. A draft resolution of a province assembly which adopts the aforementioned plan must be agreed with the Regional Director of Environmental Protection and opinionated by the provincial monument conservation officer. The obligation to execute the plan is vested in the director of a landscape park or of a complex of parks, if it was created.

\subsubsection{Landscape Parks in Numbers}

The beginnings of laying academic foundations for landscape conservation in Poland through the introduction of a landscape park concept date back to the turn of the 1950s and 1960s of the 20th century and are linked to Kraków milieu [58]. In 1971, the National Council for Nature Conservation undertook an initiative of comprehensive landscape conservation [59] and it became a pivotal moment in establishing the nature conservation system in Poland [60]. At that time, a draft of the nature conservation system was created, consisting of national parks, nature reserves and two new forms: landscape parks and protected landscape areas (then called "protected landscape zones"), which were jointly referred to as the Multi-Spatial System of Protected Areas [59]. Objectives of this concept were very modern and still remain valid. A principle of surrounding the areas of high level of protection with areas of lower protection regime was introduced as well as of joining protected areas by ecological corridors, in accordance with the Protected Areas Ecological System theory [61]. This is why in Poland, the majority of national and landscape parks have buffer zones or are surrounded by protected landscape areas (Figure 2). 


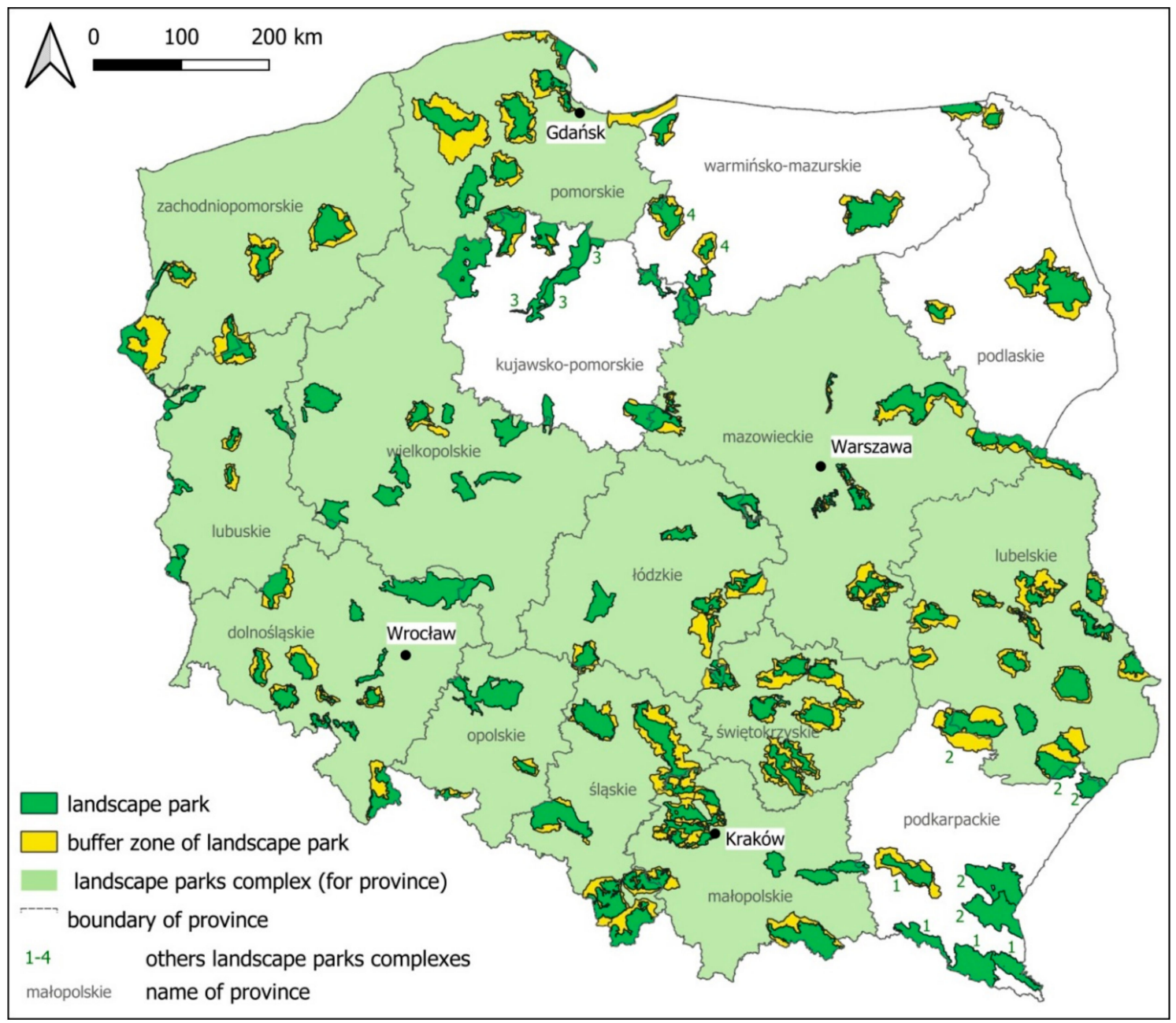

Figure 2. Distribution of landscape parks in Poland (based on: [30]).

The first landscape park in Poland was established by way of resolutions of People's Provincial Councils in 1976 and it was Suwalski LP (in the present Podlasie Province), and a year later Mazurski LP (in the present Warmia-Masuria Province). First LPs appeared in the northern part of the country—on Suwałki and Masuria Lakelands as well as in Pomerania, then subsequently in southern regions, primarily in Lesser Poland and Silesia [62]. A legislation enabling their legal protection and establishment was introduced as late as in 1980 by Act of 31 January 1980 on the protection and shaping of the environment [63], while the first regulatory definition of the parks appeared in the Nature Conservation Act of 1991. Still, the majority of LPs in Poland was established in the years 1986-2000.

Currently there are 125 landscape parks in Poland (Table 1, Figures 1 and 2) with a total area of more than $26,000 \mathrm{~km}^{2}$ [64]. For 86 of them the buffer zones were additionally created, with an area of nearly $15,000 \mathrm{~km}^{2}$ [30]. In total, landscape parks together with their buffer zones take up more than $13 \%$ of the area of Poland. In some cases, when a large number of landscape parks of a limited size appear in a given area, landscape parks complexes (further: "LPC") have been formed. In Poland, 111 parks have been combined to create 16 landscape parks complexes. Among them, 12 are of the provincial level (e.g., Lublin Landscape Parks Unit, Landscape Parks Complex of the Lesser Poland Region, Complex of Landscape Parks in Pomerania) and 4 of them are linked to geographic regions (Figure 2). Other landscape parks are independent. The average area of a park in Poland is approximately 21,000 hectares and the parks of an area from 5000 to 30,000 ha are the most common [65]. 


\subsubsection{Possibilities of Conducting Economic Activity, Including Mining}

Activities carried out in the area of the execution of a landscape park in Poland are not absolutely subservient to nature conservation $[54,56]$. Conducting economic activity is permissible in a limited scope and provided that special care for the environment is taken. The essence of the sustainable development referred to in the statutory definition of a landscape park indicates that in the area of this protection form, both the nature conservation and the economy are of importance. Moreover, conducting such activity is often a prerequisite of values for which these forms have been established [57]. It is a key factor for, among other things, the protection of cultural landscape and particularly refers to extensive farming. It is attested by Article 16 (in Section 6) of the Nature Conservation Act, which states that on farming and forestry lands located within the boundaries of a landscape park the economic activity shall be continued [54] and, therefore, utilisation of such lands for purposes other than farming and forestry respectively, is highly undesirable.

Restrictions applicable to land development may not be overly stringent as such a form is reserved solely for the forms with the highest possible protection regime, in other words, national parks and nature reserves. At the same time, the area of LPs in Poland is so large (reaching as much as ten or more $\%$ in some provinces) that imposing a great number of stringent prohibitions would result in limited possibilities of economic development for the regions, especially those where tourism and agriculture are not the main source of income.

Nevertheless, according to the Nature Conservation Act [25] and the "landscape act" [27] amending it, establishing an LP may result in numerous administrative and legal bans that may limit or even rule out economic activity (different than farming and forestry). Depending on the park specificity, the list of restrictions may differ and they may be chosen from the exhaustive list of prohibitions set out in the aforementioned law. They are imposed by an authority competent with forming the landscape park, that is by an assembly of a province. Establishing of the so-called "landscape protection zones" (for example, around a viewing point or developed areas characteristic for local architecture forms) or objects of significance in terms of history or culture is a reason why certain prohibitions become mandatory. The choice of such prohibitions in this case depends on whether such an area is covered by a local planning document or not.

In practice therefore, legal regimes imposed on the area of a landscape park may vary, but none of the prohibitions, whether mandatory or imposed by way of choosing an appropriate ban meeting the needs of an individual landscape park, is of the absolute nature [54]. In specific cases derogations are then possible.

Under Article 73 of the environmental protection law [26] limitations resulting from establishing a landscape park must be taken into account not only in regional (provincial) and local (community) planning documents but also in individual land planning permissions (in the absence of planning documents) which is extremely detrimental to home owners. Thus, it may limit the freedom of property use. Additionally, the public is not a part of the process of landscape park establishing and, in consequence, land owners are not aware of limitations which are imposed on them and they learn about this fact in their attempt to commence a specific administrative procedure. When a landscape park has been established, it is the park, and not the residents' will, that determines the manner a specific area will be developed [66].

Of the 14 prohibitions defined in the Nature Conservation Act [25] at least a few can be mentioned:

- $\quad$ "performing undertakings that (always or potentially) may significantly affect the environment within the meaning of the provisions of the Act of 3 October 2008 on the Provision of Information on the Environment and its Protection, the Participation of Public in the Environmental Protection and Environmental Impact Assessments" [28],

- "the elimination and destruction of mid-field, roadside and waterside trees (...)",

- "the extraction of rock, including peat, and fossils, including fossil residues of plants and animals, as well as minerals and amber for commercial purposes", 
- "the performance of earthworks which permanently deform the relief, except in connection with storm, flood or slide protection (...)",

- "making changes to water relations if such changes do not serve the conservation of nature or the rational management of agriculture, forestry, water or fishing".

Additionally, in the so-called landscape protection zones not covered by the local plan, the following may be prohibited [27]:

- "locating new building objects",

- "locating new building objects differing from the local architectural form",

- "locating new building objects with a height exceeding 2 storeys or $7 \mathrm{~m}$ ",

- "afforestation".

It is worth mentioning that the first of the above prohibitions enables the execution of undertakings for which the procedure of environmental impact assessment proved there is no adverse effect on the landscape park's nature, and the preparation of the environmental assessment report is not mandatory. Nevertheless, the list of undertakings that may significantly affect the environment comprises, in Poland, of 53 items for undertakings that may always significantly affect the environment and 108 items for undertakings that potentially may significantly affect the environment. Among them, the following ones may be mentioned: extraction of minerals from the deposit by way of the open-cast method in the mining area not smaller than 25 hectares, but also installations for processing these minerals (undertakings that always may significantly affect the environment) and extraction of minerals from the deposit using the open-cast method regardless of the size of the mining area if it is located within a landscape park or its buffer zone (undertakings that potentially may significantly affect the environment) [29]. It should be stressed that according to Polish legislation, the environmental impact assessment of an undertaking is part of a procedure for issuing a decision on environmental conditions for conducting business activities (including mining). This decision in turn, under the geology and mining law, is a mandatory element in the process of obtaining the mining licence. It is vital that a landscape parks complex (or a landscape park if existing independently) has certain competences in relation to the mining activity. Individual commune offices on whose territory deposits are located, may request an opinion from LPC or LP on the plan of extracting minerals in their area. Evidentiary proceedings on the environmental conditions for an undertaking consisting in the management of deposits, however, are run by communal offices.

The aforementioned prohibitions are only examples out of many other defined in the legislation, which may limit conducting such a specific form of business activity as open-cast extraction of minerals. The conflict of divergent forms of land use, which is the conservation of landscape in the form of a landscape park and of the mining activity is not a rare circumstance in Poland. Nearly every time such a conflict is resolved on a discretionary basis, and as is often the case, it is resolved to the detriment of the mining activity [67]. Among other things, it results from the fact that such activity is usually categorised as the one which requires the procedure of environmental impact assessment together with a report to be carried out. For this procedure, participation of the public is mandatory. The public in most cases clearly opposes new mining investments and is usually supported by supralocal or local non-governmental organisations whose goal is to protect the environment $[68,69]$. In practice therefore, despite the lack of formal prohibition for minerals extraction within an LP boundaries, resolutions of provincial assemblies establishing an individual park actually bans this type of activity and only a few allow exceptions in this respect. The most favourable situation from the point of view of a mining entrepreneur is when an LP is created after the deposit extraction has begun, or when an entrepreneur operating within the park's boundaries applies for the extension of the licence. Entrepreneurs who decide on "green field" activity in an undeveloped area lacking necessary infrastructure and the tradition of mining are in the least favourable position. In these circumstances, the process of proving that the extraction of a mineral may be of supralocal importance and surpasses values that a landscape park is supposed to protect becomes extremely cumbersome. 


\subsubsection{Open-Cast Mining in Landscape Parks in Poland}

Currently in Poland, the extraction in landscape parks is carried out within the boundaries of 133 rock mineral deposits, of which 88 are deposits of natural sand and gravel aggregates and 20 are deposits of dimension and crushed stones. Peats for medical purposes are also extracted in landscape parks (9 deposits) as well as limestone and marl for the lime industry ( 5 deposits). Other minerals are represented by single deposits (Table 2). From the dominating group of natural aggregates, the majority of extracted deposits (74) are small deposits with a mining area not exceeding four hectares and the extraction not higher than a 100,000 tonnes. Nearly half of them, despite having a valid mining licence, do not operate or its operation is of periodic nature. As a result, in 2018, within the boundaries of landscape parks as little as $2.7 \%$ of natural sand and gravel aggregates were extracted in Poland. In the group of dimension and crushed stones, a similar situation can be observed. In 2018, deposits located in LPs accounted for not much more than $4 \%$ of domestic production of this raw material (Table 2), but it was achieved through the operation of just three deposits where over 900,000 tonnes were extracted.

Deposits of limestone and marl for the lime industry deserve commentary. Although in Poland 120 documented deposits can be found [9], but their extraction is performed only in 22 deposits, including five operating within landscape parks. As a result, more than $40 \%$ of domestic production of this raw material comes from mines operating in the boundaries of this form of nature conservation. The largest limestone deposits extracted in Poland for the needs of the lime industry are the Ostrówka deposit (owned by Nordkalk Corporation) and the Czatkowice deposit together with the limestone mine (KW "Czatkowice"), presented in detail in this paper.

Another 283 rock mineral deposits are extracted in landscape parks' buffer zones in Poland. Among them, the most numerous group is again the natural aggregates deposits (216), further dimension and crushed stones (48) and clay raw materials for construction ceramics (7). In the buffer zones peats for medical purposes, limestone and marl for the lime industry, quartz sands for the production of cellular concretes and limestone and sand brick, ceramic and stoneware clay as well as filling sands are also extracted (Table 2).

From the dominating group of natural aggregates, the majority of extracted deposits (181) are small deposits with a mining area not exceeding 10 hectares and the extraction not higher than a 50,000 tonnes per year. Nearly a half of them, despite having a valid mining licence, do not operate or operation is of periodic nature. As a result, in 2018 within the boundaries of landscape parks' buffer zones as little as $5.7 \%$ of natural sand and gravel aggregates were extracted in Poland. It should be added, however, that for some of them the licences were issued in 2018 or 2019, and hence at the end of 2018 they did not show any extraction. In 2018, dimension and crushed stones deposits located in LPs' buffer zones accounted for 19\% of domestic production of this raw material (Table 2, the minerals related to the "Czatkowice" Limestone Mine are highlighted in orange), what was primarily contributed to by four deposits in which over 800,000 tonnes were extracted.

Furthermore, three subsequent limestone and marl deposits producing for the lime industry are located in buffer zones, including the Trzuskawica deposit, which is, in terms of extraction, the second largest deposit of this raw material in Poland. As a consequence, more than $2 / 3$ of limestone for the lime industry used in Poland, for example, for the production of limestone sorbents, is obtained from deposits located in landscape parks or their buffer zones. 
Table 2. Extraction of minerals within the boundaries of landscape parks and their buffer zones in Poland (status as at 31 December 2018) (based on: [9,30,31]).

\begin{tabular}{|c|c|c|c|c|c|c|c|c|c|}
\hline \multirow[b]{2}{*}{ Mineral } & \multicolumn{3}{|c|}{ Landscape Parks } & \multicolumn{3}{|c|}{ Buffer Zone of a Landscape Parks } & \multicolumn{3}{|c|}{ Total } \\
\hline & $\begin{array}{l}\text { Number of } \\
\text { Deposits }\end{array}$ & $\begin{array}{c}\text { Extraction } \\
(1000 \mathrm{t}) \\
\left(* 1000 \mathrm{~m}^{3}\right) \\
\end{array}$ & $\begin{array}{c}\text { Extraction } \\
\text { (\% of Domestic } \\
\text { Extraction) }\end{array}$ & $\begin{array}{c}\text { Number of } \\
\text { Deposits }\end{array}$ & $\begin{array}{c}\text { Extraction } \\
(1000 \mathrm{t}) \\
\left(* 1000 \mathrm{~m}^{3}\right) \\
\end{array}$ & $\begin{array}{c}\text { Extraction } \\
\text { (\% of Domestic } \\
\text { Extraction) }\end{array}$ & $\begin{array}{c}\text { Number of } \\
\text { Deposits }\end{array}$ & $\begin{array}{c}\text { Extraction } \\
(1000 \mathrm{t}) \\
\left(* 1000 \mathrm{~m}^{3}\right) \\
\end{array}$ & $\begin{array}{c}\text { Extraction } \\
\text { (\% of Domestic } \\
\text { Extraction) }\end{array}$ \\
\hline $\begin{array}{l}\text { Natural aggregates } \\
\text { (sand and gravel) }\end{array}$ & 88 & 5354 & 2.7 & 216 & $11,174.5$ & 5.7 & 304 & $16,528.5$ & 8.4 \\
\hline Dimension and crushed stones & 20 & 3468 & 4.2 & 48 & $15,794.0$ & 19.4 & 68 & 19,262 & 23.6 \\
\hline Peat for medical purposes & 9 & $8.56^{*}$ & 0.6 & 2 & $3.5^{*}$ & 0.2 & 11 & $12.06^{*}$ & 0.8 \\
\hline Limestone and marl for lime industry & 5 & 7590 & 40.4 & 3 & 4258.6 & 22.7 & 8 & $11,848.6$ & 63.1 \\
\hline Quartz sands for production of cellular concrete & 3 & $93^{*}$ & 20.2 & 1 & $40.2 *$ & 8.8 & 4 & $133.2 *$ & 29.0 \\
\hline Building ceramics raw materials & 2 & $32 *$ & 1.6 & 7 & $57^{*}$ & 2.8 & 9 & $89 *$ & 4.4 \\
\hline Quartz sands for production of lime-sand brick & 2 & $139.3 *$ & 25.0 & 2 & $94.6 *$ & 16.8 & 4 & $233.9 *$ & 29.0 \\
\hline Dolomites & 1 & 189.15 & 6.0 & - & - & - & 1 & 189.15 & 6.0 \\
\hline Phyllite schists & 1 & 159.99 & 100 & - & - & - & 1 & 159.99 & 100 \\
\hline Clay raw materials for cement production & 1 & & - & - & - & - & 1 & & \\
\hline Raw materials for engineering work & 1 & $45^{*}$ & 13.6 & - & - & - & 1 & $45^{*}$ & 13.6 \\
\hline Stoneware ceramic clays & - & - & - & 2 & 21.4 & 7.9 & 2 & 21.4 & 7.9 \\
\hline Backfilling sands & 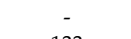 & - & - & 2 & 1000.0 & 33.1 & 2 & 1000.0 & 33.1 \\
\hline TOTAL & 133 & - & - & 283 & - & - & 416 & & \\
\hline
\end{tabular}

* in $1000 \mathrm{~m}^{3}$; The minerals related to the "Czatkowice" Limestone Mine are highlighted in orange. 


\section{3. "Czatkowice" Limestone Mine—Case Study}

\subsubsection{Historical Outline and General Characteristics}

In 1994, as part of the Convention on Long-Range Transboundary Air Pollution, Poland signed the Second Sulphur Protocol on limiting sulphur dioxide emissions. As a result, Poland faced the task of reducing the overall load of $\mathrm{SO}_{2}$ emissions and meeting, by both existing and newly commissioned power facilities, the $\mathrm{SO}_{2}$ emission standards at the level that guarantees $90 \%$ desulphurisation efficiency [70]. The Polish professional power sector has been traditionally based on hard coal and lignite firing that entails the need to use absorbents ensuring the efficiency required. This is achieved by applying the so-called lime meal obtained from carbonate rock [71] or lime sand of slightly coarser grain size. The progress of implementation of desulphurisation methods in the Polish professional power sector (thus, also in industrial power sector and partially in heating sector) resulting from international treaties and from internal regulations has contributed to the development of domestic demand for lime sorbents [72]. Among nine producers of sorbents for flue gas desulphurisation by lime methods operating in the Polish market (based on data from the Lime Industry Association [73]), the "Czatkowice" Limestone Mine is of the greatest importance, owned by the TAURON Group and located in southeast Poland, in Lesser Poland Province (Figures 3 and 4).

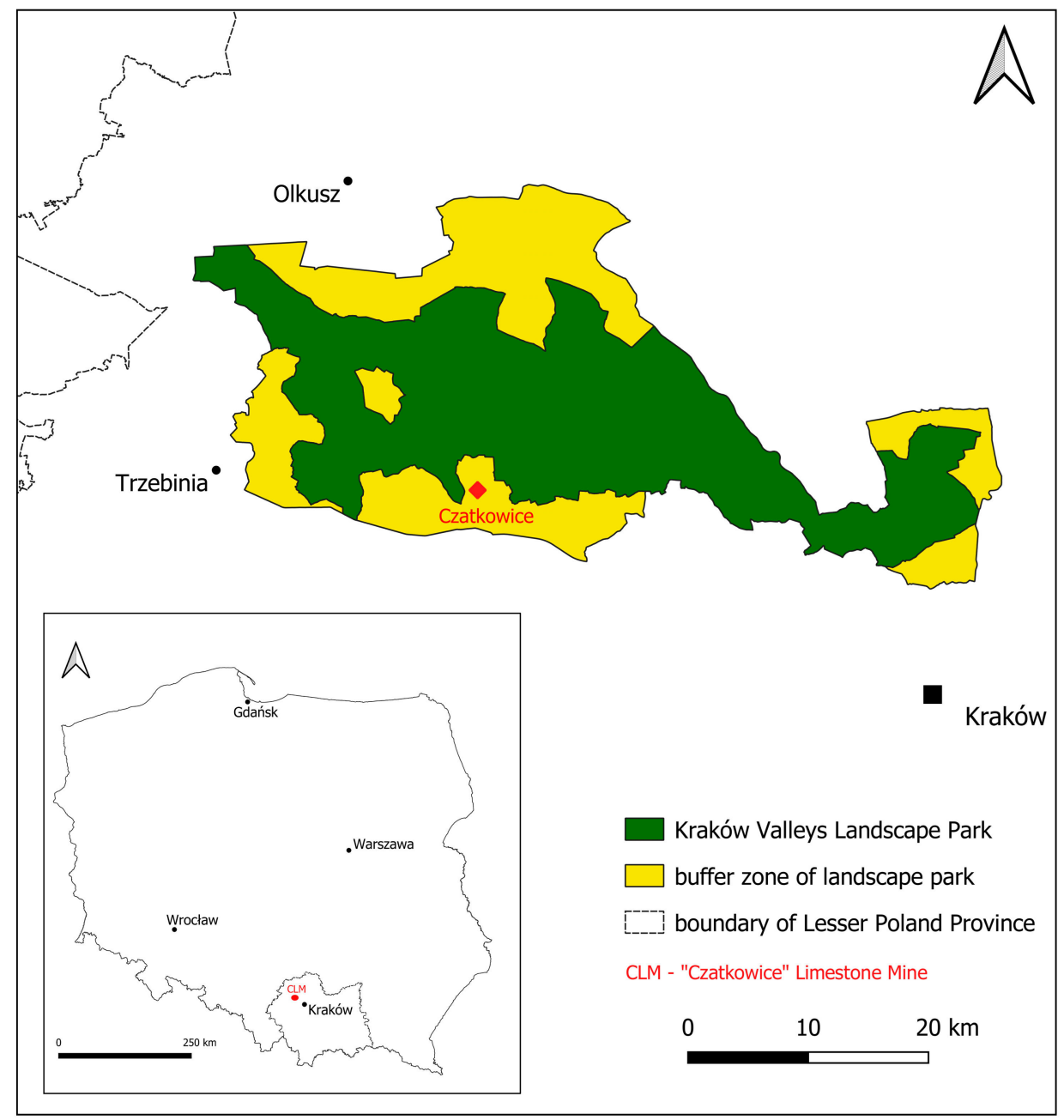

Figure 3. Location of "Czatkowice" Limestone Mine. 

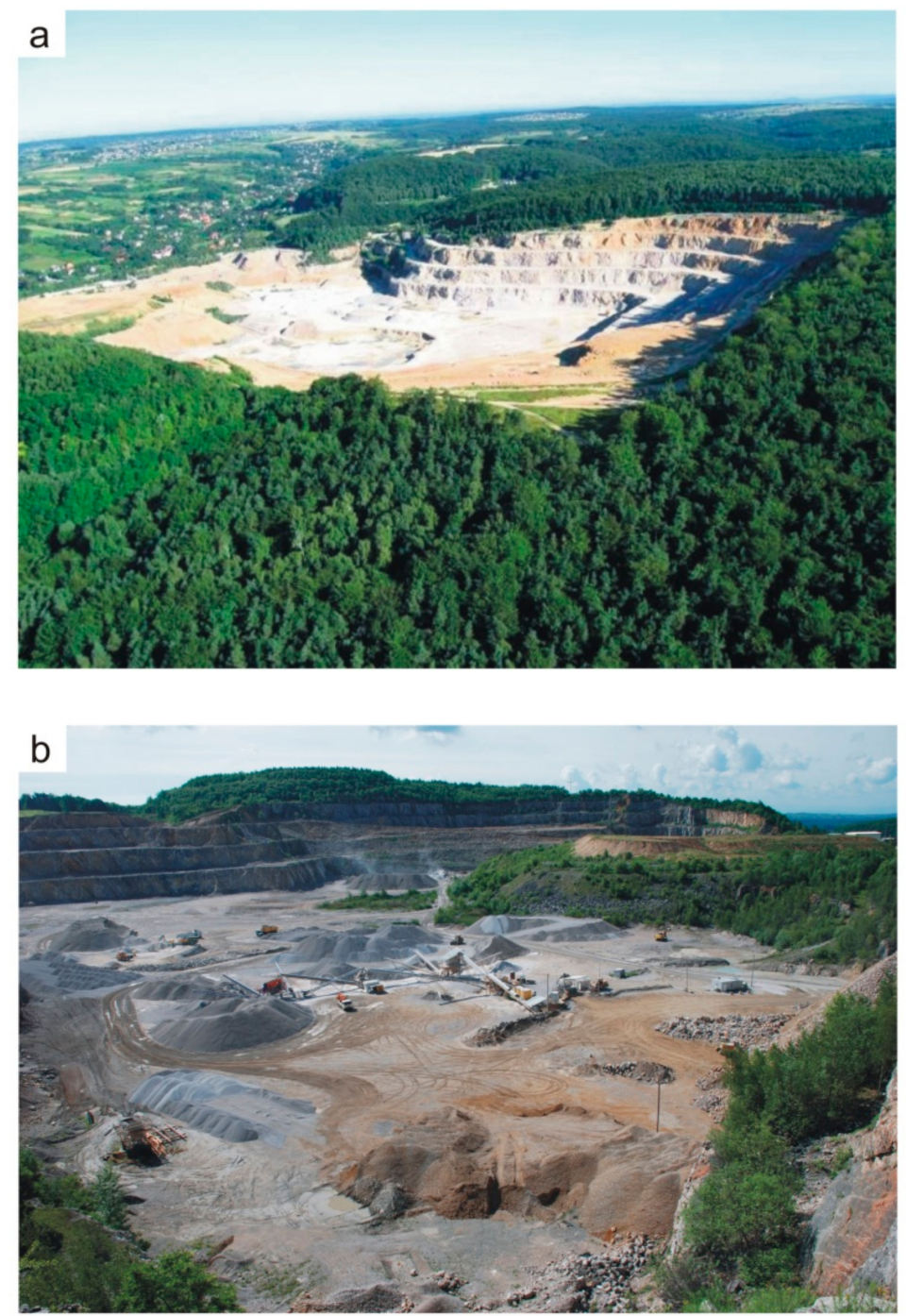

Figure 4. "Czatkowice" Limestone Mine: aerial view of mine and surrounding forest areas (a) and general view of open pit with exploitation levels (b) (source: KW “Czatkowice"—own archives).

The exploitation of the Czatkowice deposit, already known before World War II, was started by Germans in 1942. High-quality limestone was extracted, then used for carbide production. After a break resulting from war operations, in 1947 the quarry was taken over by Poles and a year later the industrial scale production was already launched [74]. The total limestone (50,000 tonnes/year) was used by the steel industry-for the blast furnace stone and stone processed into quicklime. The fact that the mine was considered the primary source of raw materials (metallurgical fluxes) for Lenin Steelworks located nearby in Kraków forced its further extension and the increase in its production capacities to 1,700,000 tonnes per year in 1967. It entailed the extension of the processing plant in the beginning of the 1970s, which after extension and modernisation operates until today. In 1969 the enterprise adopted its current name: the "Czatkowice" Limestone Mine. In subsequent years the company reached record production and sales of raw material on the level of 3,500,000 tonnes [75].

The year 1989 brought not only political, by also economic changes. The turbulent period of political changes resulted in reduced demand for limestone among the CLM's main customers which, at that time, were steelworks, chemical plants, cement plants and sugar refineries. It put the mine in a very difficult financial situation but, on the other hand, gave rise to a new chapter in its operation in the Polish market. The mine began to be considered as a potential source of raw material in the process of flue gas desulphurisation by power plants. Finally, in 1996 the state-owned company was 
transformed into a commercial law company under the name Kopalnia Wapienia "Czatkowice" sp. z o.o. Among the owners were three large power plants, which comprised 51\% of the company's shares. A new model of operation was developed that envisaged three main product groups: limestone for the metallurgy and cement industries, products of limestone processing for the power industry and aggregates for construction. In subsequent years a substantial modernisation of the processing plant took place, both in the production of aggregates and, first of all, the erection of two limestone milling lines. This stage was only completed in 2008. In December 2010, a usufruct in LCM's shares was granted to TAURON Polska Energia SA, and then in 2014 the shares were transferred to this company.

Currently, the mine is a major producer of high-quality limestone meal and sands, utilised, for example, as sorbents in the flue gas desulphurisation technology in the power industry. The exploitation of high-quality raw material and the technologies of limestone processing guarantee excellent parameters of the assortment produced. Nowadays, the offer of the company ranges from products aimed foremost for the power and metallurgy industries to those directed to the construction industry, road building, agriculture, cement plants and underground mining (limestone dust) [76]. The extraction of limestone for processing purposes is adapted to the needs of the company's customers and for several years it has remained at the level of approximately 1,600,000-2,000,000 Mg $(1,650,000 \mathrm{Mg}$ in 2018) [9], whereas the limestone meal and sand account for $41 \%$ of production and the aggregates for approximately $48 \%$. The extraction is carried out using the open-cast mining method (Figure 4), the plunging method-on five exploitation levels (to $100 \mathrm{~m}$ of depth). The deposit is worked by means of long blast holes and the blasting is carried out once a day. The mining surface area, in other words, the space where the mine may carry out extraction works is 134 hectares, and the mining land (space with anticipated mining impacts)) is 444 hectares.

Currently, the mine produces approximately $40 \%$ of sorbents for flue gas desulphurisation available in the Polish market. The CLM provides raw material for the largest power plants in southern and central Poland, belonging mostly to the TAURON Group, and to others, for example, the Bełchatów Power Plant, which meets $22 \%$ of domestic energy demand and is the largest conventional power plant fuelled by lignite in Europe.

\subsubsection{Environmental and Spatial Conditions of Mining Activity}

The "Czatkowice" mine had to face environmental protection issues since the day of its founding and they contributed to the shaping of the first post-war project of deposit exploitation. At that time the attention was drawn to natural and cultural values of the north-east neighbourhood of the mine, where the Eliaszówka Valley is found (a nature reserve with strict protection) as well as a monastery complex entered into the register of monuments [75] (Figure 5). As the mine developed and the public awareness as well as legal conditions and related requirements changed over time, the company dealt with the issues of water protection, air protection and reclamation of land. In subsequent years, they were joined by issues related to landscape conservation, forests and land development.

Concurrent with changes in the profile of production and the ownership came the need for expansion of the mine's resource base due to increasing demand for its products. The aim was to obtain a licence for a new deposit section with an area of 48 hectares, which finally led to acquiring ownership rights (lease or purchase) to approximately 80 hectares of land, due to the need of forming a forested protective belt around the north-east border of the extended deposit. However, the extraction licence obtained by the mine in 1996 was valid for a period of 30 years (until 2026), but the sufficiency of the deposit resources was estimated on the year 2020. Activities aimed at obtaining a new licence had to be preceded by documenting the new deposit section, which was concluded in 2009 with the approval of respective documents for the deposit and its geological resources. 


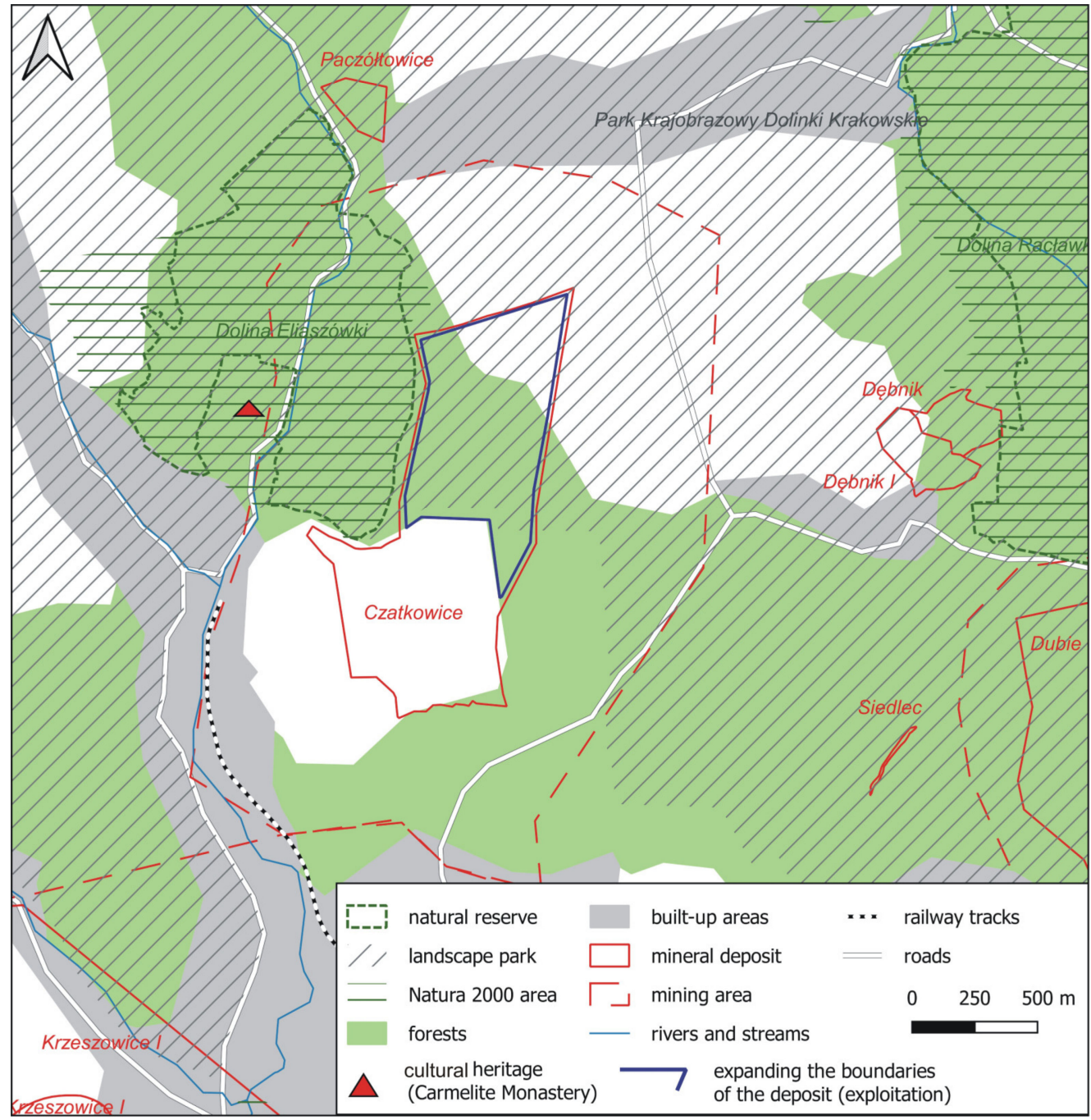

Figure 5. Location of "Czatkowice" LM as compared with environmental conditions.

The most important element of the new licence process was the fact that the new deposit section was located within the boundaries of the Kraków Valleys Landscape Park, where the prohibition of mining operation is in force. To date, the mine has carried out its activities in this park's buffer zone. The unique landscape, an exceptional natural value of the existing valleys as well as the need to preserve their natural character contributed to the creation of a landscape park in their area in 1981. It takes up an area of 20,686 hectares and is a part of the Lesser Poland Province Landscape Parks Complex. It stretches across a very interesting area between Kraków in the east, Trzebinia in the west and Olkusz in the north (Figure 3).

As mentioned in Section 3 of this paper, the resolution establishing the LP takes precedence over other documents, including planning documents. Therefore, obtaining the licence first required lifting of the ban on exploitation through an appropriate resolution of the Lesser Poland Province Assembly, which in 2011 exempted the new deposit from the ban. The Regional Director of Environmental Protection in Kraków issued positive support to the provisions of the draft resolution of the Lesser Poland Province Assembly, stating that:

"the change in the protection regime of the Kraków Valleys Landscape Park in the area of the carboniferous limestone deposit "Czatkowice" is justified for economic and environmental reasons. It enables the continuation of exploitation of the remaining part of the deposit by the "Czatkowice" Limestone Mine, which supplies several of the largest power plants in 
south-western Poland with sorbents for the power industry, used for flue gas desulphurisation in the fluidized bed combustion technology. Moreover, carboniferous limestone is used for construction purposes, including road construction". [77]

Only this element enabled further legal and administrative actions. These actions included: (1) changing the provisions of local planning documents (study of conditions and directions of spatial development of the commune within the boundaries of which the deposit is located and the local plan within the boundaries of the projected mining terrain); (2) carrying out an environmental impact assessment (EIA) together with a report; (3) obtaining, on the basis of the EIA procedure, a decision on the environmental conditions of conducting the mining activity; and (4) preparing a deposit development project. It is worth mentioning that the change in the provisions of the commune's study entailed the conversion of agricultural and forest land use. In Poland, a consent for such a transformation lies with the competence of the Minister of Agriculture and Rural Development and the Minister of Environment, respectively.

The decision on environmental conditions (the so-called environmental decision), an extract from planning documents of an individual commune (with the appropriate-mining or industrial direction of use of a given area) and the deposit development project are mandatory appendices in the procedure for obtaining a mining licence in Poland.

Finally, in August 2014, an application for the modification of the licence was submitted and on 22 October 2014 the mine obtained a decision enabling the exploitation of the newly documented part of the deposit. Ultimately, it will be an area of about 48 hectares, of which 29 hectares originally belonged to the state forests, while the remaining 19 hectares were in private hands and were purchased by the mine. Another 33 hectares, which are located outside the deposit's boundaries (to the north and north-east direction) have also been purchased from private individuals, in order to create a 200-m wide forested protection belt even before the extraction of the new part of the deposit is started [78]. On the one hand, the role of the belt is to take over the natural function of the felled forest and ensure the continuity of ecological corridors, and on the other hand, to provide a natural barrier against noise and dust emissions. In this part, the mining area of the mine lies in the proximity of housing estates. The new licence is valid until 31 December 2060.

To sum up, the extension of the "Czatkowice" deposit is an elongation of the currently exploited deposit to the north. It is located in the Kraków Valleys Landscape Park and its western border is directly adjacent to Natura 2000 area, but also to the strict protection area of the Eliaszówka Valley Reserve (Figure 5). Both the reserve and the Natura 2000 area are located within the boundaries of the mining land, therefore in the area potentially affected by extraction works of the mining plant. Additionally, in the area affected by the mine a historic monastery complex of the Blessed Carmelites can be found as well as a secondary containment zone of three drinking water intakes for the commune. Due to the above, the decision of environmental conditions for this mining project includes 26 items describing all steps which the mine must take to protect the landscape and nature. Additionally, the CLM undertakes other activities to improve the quality of the environment in the mine area and around the plant. Among them should be mentioned (order in accordance with the decision of environmental conditions) [79]:

- afforestation of protective strip (200 $\mathrm{m}$ in width) in an area of about $33 \mathrm{ha}$;

- creating an additional forest strip as a protective zone along the boundary of the Eliaszówka Valley Reserve (minimum $40 \mathrm{~m}$ in width and $620 \mathrm{~m}$ in length);

- conducting mining works only during the daytime;

- minimisation of lighting of the area including the use of appropriate lamps;

- the place of blasting depends on the season (e.g., in autumn and winter in proximity to the Natura 200 area);

- periodic monitoring of air pollution and monitoring of tree stand quality in the Eliaszówka Valley Reserve and the Natura 2000 area; 
- monitoring of bat population (including monitoring of bat habitat quality) in the indicated sites;

- installation of 100 boxes for bats within the new forest buffer zone;

- installation of trapnests and periodic monitoring of birds;

- creating reproductive ponds for amphibians (with the indicated minimum area and depth) and their period monitoring;

Moreover the CLM carries out actions in the field of:

- reduction of dust emission by modernization of selected technological lines;

- reduction of noise emission by appropriate sound-proofing of technological nodes and communication routes;

- $\quad$ orderly water and sewage management including mechanical and biological sewage treatment plant, settlement tanks for the separation of petroleum products from rainwater, settlement tanks for capture of solids washed off roads and squares,

- introduction of more greeneries as acoustic enclosures,

- other actions reducing the consumption of heat and other natural resources (modernisation of heating system including thermo-modernisation of buildings and modernisation of boiler room, reduction of industrial water consumption and wastewater discharge to the stream, reduction of the consumption of natural gas necessary in the grinding process).

\section{Discussion of Factors of Risk and Success}

The procedure for obtaining a mining license, starting with the identification of the deposit's resources and ending with a valid decision authorising the exploitation, was a complex and lengthy process. The fundamental importance of the case was to obtain derogation from the ban on limestone mining in the area of Kraków Valleys Landscape Park (Table 3). In order to obtain the final licence decision, the proceedings with public participation at the local level had to be successfully completed, related to, for example, changes in planning documents of the commune and the environmental impact assessment procedure. Positive opinions issued during the proceedings with the public participation are probably also a result of the company's management informational campaign directed at the local community referring to the planned and implemented activities pertaining to the extension of the operation area. Organisation of meetings with the local community in advance, during which the mine presented its most recent plans in detail proved to be good practice. The meetings, which took the form of open dialogue with stakeholders, resulted in positive residents' response to the envisaged extension of the mining area, providing that plots of land in a protection strip of approximately 33 hectares would be purchased. The decisive argument in this respect was the decline in the value of these plots, due to the future limited possibility of using them for recreational or residential purposes.

As the exploitation of the Czatkowice deposit has been going on for several decades, the local community sees positive aspects related to mining activities in the commune. These are certainly indirect financial benefits, in other words, the commune's income from taxes and the mining fee, but also direct benefits achieved through sales of plots of land intended for the exploitation and the protective strip. The extension of the licence allowed maintaining employment in the company at the current level, and the employees and their families are mainly close neighbours of the mine, which was and is a very important factor too. Another important factor was increasing public awareness of the fact that the extraction and processing of stone and its subsequent use as a sorbent in the power industry brings benefits not only locally but also nationwide, improving the quality of atmospheric air through the elimination of $\mathrm{SO}_{2}$ from energy flue gases. 
Table 3. Risk factors of Czatkowice extraction.

\begin{tabular}{|c|c|c|c|}
\hline & Risk/Description of Risk & $\begin{array}{c}\text { Strategy of Risk Management } \\
\text { (Acceptance, Avoidance, Elimination, Reduction, Transfer, Increase, no } \\
\text { Strategy) } \\
\text { (What Actions Have Been Taken?) }\end{array}$ & $\begin{array}{c}\text { Response to Risk } \\
\text { (Planned Actions, Evaluation of Performed Activities, Comments) }\end{array}$ \\
\hline Corporation risk & $\begin{array}{l}\text { Lack of corporate consent regarding finance the project, resulting in } \\
\text { non-implementation of the investment-in 2022, exhausting the resources } \\
\text { of the Czatkowice I deposit and liquidation of a company }\end{array}$ & $\begin{array}{l}\text { Application to the proper corporate authorities with a feasibility study (of } \\
\text { new project) along with a financial projection showing the effectiveness and } \\
\text { legitimacy of the investment project implementation (elimination) }\end{array}$ & $\begin{array}{l}\text { Supplementing the feasibility study, taking into account the guidelines of corporate } \\
\text { authorities }\end{array}$ \\
\hline \multirow{3}{*}{ Licence risk } & $\begin{array}{l}\text { Factors of risk: } \\
\text { - limited time for licence obtaining (risk of loss the right to the } \\
\text { exclusive use of geological documentation of the Czatkowice II } \\
\text { deposit and the need to repeated buy of the right to use } \\
\text { geological information) }\end{array}$ & $\begin{array}{l}\text { Conducting intensified legal and formal activities aimed at obtaining of } \\
\text { mining licence: } \\
\text { - submitting an application to the Krzeszowice Municipal Office to } \\
\text { obtain a decision on environmental conditions for the investment; } \\
\text { application to the Marshal of the Lesser Poland Province for a consent } \\
\text { for a deviation from the extraction ban in Kraków Valleys Landscape } \\
\text { Park (elimination) }\end{array}$ & $\begin{array}{l}\text { Submitting an application for an extraction license, preceded by following steps: } \\
\text { - obtaining a consent for a deviation from the extraction ban in Kraków Valleys } \\
\text { Landscape Park, } \\
\text { - legal title (owned by the "Czatkowice" Limestone Mine) to land properties in } \\
\text { proposed boundaries of mining area, } \\
\text { approval by the Marshal of the Lesser Poland Province of the Deposit } \\
\text { Development Project, previously approved by the competent } \\
\text { mining supervision, } \\
\text { - determination the mining area and mining land (by the Marshal of the Lesser } \\
\text { Poland Province) } \\
\text { - obtaining a positive decision regarding changes in Local Spatial Development } \\
\text { Plan of Krzeszowice Municipality and Commune (forest and agriculture areas } \\
\text { have been changed to industrial areas) }\end{array}$ \\
\hline & $\begin{array}{l}\text { - protracted procedures of public administration organs-long wait } \\
\text { for decision of the Marshal of the Lesser Poland Province regarding } \\
\text { consent for a deviation from the extraction ban in Malopolska } \\
\text { Valleys Landscape Park }\end{array}$ & $\begin{array}{l}\text { - application to the Marshal of the Lesser Poland Province for a } \\
\text { deviation from the extraction ban in Kraków Valleys Landscape Park, } \\
\text { supplementing the Report of Environmental Impact } \\
\text { Assessment-additional information regarding cumulative impact } \\
\text { assessment of CLM and "Dẹbnik" quarry (reduction) }\end{array}$ & Dialogue with the Marshal's Office of the Lesser Poland Province \\
\hline & $\begin{array}{l}\text { - Protests and lack of social acceptance, including the lack of consent } \\
\text { to the sale of properties (the lack of purchase of lands makes it } \\
\text { impossible to start the licensing process) }\end{array}$ & $\begin{array}{l}\text { - open direct dialogue between public and representatives of Corporate } \\
\text { and mine } \\
\text { - extensive activity of CLM in the area of CSR } \\
\text { conducting the talks and negotiations with landowners by the } \\
\text { professional company } \\
\text { publicising an information about the planned } \\
\text { investment implementation } \\
\text { publicising an information about planned purchase of land over the } \\
\text { documented deposit and within protection zone of } 200 \mathrm{~m} \\
\text { making the Report of Environmental Impact Assessment accessible } \\
\text { to public } \\
\text { (reduction) }\end{array}$ & $\begin{array}{l}\text { Purchase of part properties and change the structure of ownership; submitting the } \\
\text { Feasibility Study to the appropriate corporate authorities in order to obtain a } \\
\text { financing decision of the project and the corporate consent to implement the project. }\end{array}$ \\
\hline $\begin{array}{l}\text { Risk of } \\
\text { environmental } \\
\text { decision }\end{array}$ & $\begin{array}{l}\text { Obtaining an unfavourable or negative decision on environmental } \\
\text { conditions }\end{array}$ & $\begin{array}{l}\text { Preparation of the report of environmental impact assessment for given } \\
\text { investment. Optimal variant for "Czatkowice" Limestone Mine (extraction } \\
\text { of all new documented resources) included set of relevant nature } \\
\text { compensation (in accordance with the Environmental } \\
\text { Protection Law) (elimination) }\end{array}$ & $\begin{array}{l}\text { Planning of mining activity with a limited environmental impact. Deforestation of } \\
\text { areas carried out in stages enabling the gradual growth of plantings (in areas } \\
\text { purchased as compensation areas in order to maintain the balance of the ecosystem) }\end{array}$ \\
\hline $\begin{array}{l}\text { Risk of price } \\
\text { variability }\end{array}$ & $\begin{array}{l}\text { Long-standing process of land purchase-real risk of price hike of } \\
\text { properties. Additional factor of price hike-amendment to the geological } \\
\text { and mining law }\end{array}$ & $\begin{array}{l}\text { Concentrated activities regarding land purchase (included consent in } \\
\text { writing of properties owners) (reduction, acceptance) }\end{array}$ & $\begin{array}{l}\text { Pursuit of purchase of the land in the shortest possible time. Submission of the } \\
\text { feasibility study to the appropriate corporation supervision authorities in order to } \\
\text { obtain a decision on starting the purchase of land. }\end{array}$ \\
\hline
\end{tabular}


The good practice of informing the public, developed during the widely understood licence procedure, is still continued in the company, which regularly organises meetings with representatives of local communities. The purpose of the meetings is the ongoing mutual exchange of information on CLM's operations, assessment of its impact on its closest neighbours and joint development of solutions to reduce the negative effects of mining operations.

The local community is also an extremely important element of the CLM's activities in the area of CSR (corporate social responsibility). The mine successfully combines business activities with all activities for the local community [80]. As a friendly and modern company, it actively and responsibly participates in the life of the local community by engaging in solving their problems and supporting all initiatives aimed at improving its functioning. It is willing to undertake activities in this area in partnership with other local entities. Many years of experience and a number of initiatives have made the mine one of the most important entities acting for the local community. Dozens of organisations and individuals have already benefited from the assistance offered, including mainly children and people with disabilities. The municipality of Krzeszowice, within the boundaries of which the mine operates, is also an important beneficiary of CLM. Modernization of road infrastructure or investments in architectural objects (including sacral) are the most important actions in this respect. The organisation or co-organisation of annual outdoor events is also important for the company's image.

"Czatkowice" Limestone Mine implements its activities according to the concept of sustainable development, thanks to which they support and supplement business objectives adopted by the mine. The sustainable development means the development taking into account both social progress (visible through the CSR activities) and ecological balance [80]. The mine strives to ensure that all its activities are carried out in accordance with the applicable norms and laws and makes continuous efforts to reduce its environmental impact. In this respect, it exceeds the obligations imposed on it by the decision on environmental conditions of exploitation, striving to make the plant safe for the environment and society. Activities aimed at reducing noise and dust emissions (including those related to increased car traffic) are a priority for the mine as well as the implementation of pro-ecological investments in accordance with the programmes established for the Lesser Poland Province, mainly concerning air protection.

All pro-environmental activities contribute to the positive image of the mine among all the stakeholders-local community, local authorities, regional institutions involved in the process of obtaining a mining license, but also among potential customers and recipients of its products. In the case of the public and the local authorities as well as the Regional Directorate for Environmental Protection in Kraków during the process of obtaining positive opinions and granting permissions, the completion of protective afforestation zone proposed by the investor was a decisive factor (Figure 6). The project of protective strip afforestation in an area of about $33 \mathrm{ha}$, minimizing the negative effects of the project implementation, was a pioneering action on the national scale, due to the approach (anticipatory action prior to the start of exploitation from a new deposit section) and its size. As a result, the forested area is equal to the area where deforestation will eventually occur as a result of exploitation, which will fully compensate for the loss of forest habitats. The mine's reclamation work, which was carried out in the area of the former porphyry quarry and the mining waste heap is also significant as well as current actions taken in this respect. Attractive forest and recreational areas have become the hallmark of the mine. 

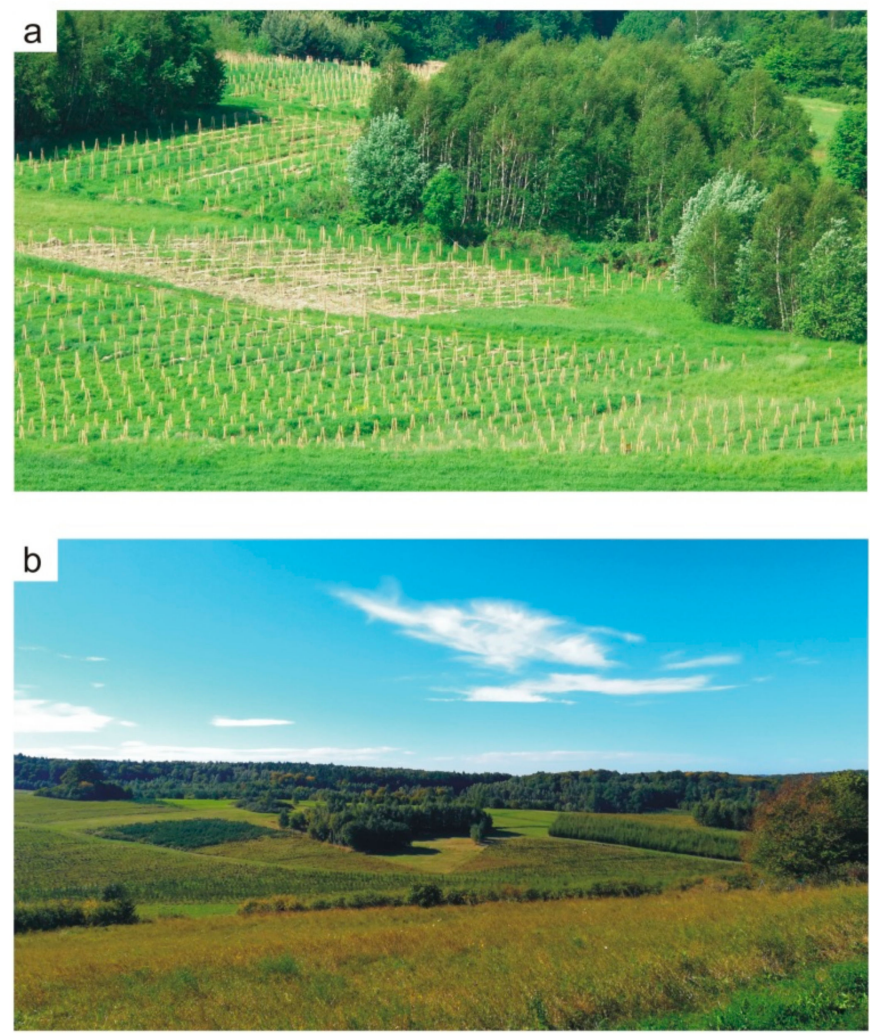

Figure 6. Forested protective strip: (a) beginning of works, (b) after 5 years (source: "Czatkowice" LM-own archives).

\section{Conclusions}

In conclusion, it should be highlighted that it is the first such comprehensive analysis of possibilities of mining activity in landscape parks in Poland. What is more, it is supported by a relevant case study. Detailed identification and analysis of risk and success factors could be relevant guideline for other mines functioning in similar conditions. The article is also relevant and uncommon in literature reviews of law conditions of mining activity in landscape parks in European countries.

Landscape parks are marked by the necessity to reconcile measures necessary for nature conservation and to ensure the possibility of conducting existing activities, including economic ones, in their territory. In this respect, it is a complex area of public intervention, which is executed through the influence of public authorities in the field of environmental protection and spatial planning. Its aim is to ensure rational management of this specific asset, which is the landscape, in conditions of constant reconciling of interests of various stakeholder groups, in particular the inhabitants of a given area, businesses operating on this territory (whose interests are not uniform) or people visiting the area [81].

In Poland, LP's constitute a very important element of the nature conservation system, covering over $13 \%$ of the country's area. Their role was strengthened after Poland ratified the European Landscape Convention [53] whose essence is that it definitely links the landscape with the economy. These two elements are equally important and should exist in harmony. Among the spatial forms of nature conservation in Poland, the landscape parks are characterised by the high (but not the highest) protection regime. The regional authorities establish landscape parks within their administrative borders and they decide which of the prohibitions-regulated by national legislation - will be introduced. Among them, there are many that may particularly affect such specific forms of economic activity as the open-cast mining. This is what happens in reality-although the landscape park protection regime allows for the exploitation of minerals, entrepreneurs encounter a number of difficulties. These are compounded by 
the lack of favour from local communities and local authorities, without whose approval the mining activities are not possible.

In Poland, the "Czatkowice" Limestone Mine deserves our attention as the one of a few to have managed to obtain a new licence to exploit its entire deposit, entering the boundaries of a landscape park for the next few decades. At the same time, this ensured stability of the company's operations until 2060. The location of the mine in the neighbourhood of many forms of nature conservation (including forms of strict protection) made the issue of nature conservation particularly important and required taking additional actions to minimise the environmental impact. In recent years, the "Czatkowice" Limestone Mine has become one of the largest manufacturers of milled limestone products in the country and has become the largest supplier of sorbents for the power industry in Poland. During the modernization of the plant, great emphasis was placed on environmental protection and its adaptation to the surrounding areas. An innovative solution in the environmental field was the forming of an extensive forest protective belt with an insulating function. The mine was the first in the country to propose such a solution.

Apart from direct pro-ecological activities, the mine, acting in accordance with the idea of sustainable development, has been emphasizing CSR activities for many years. The priority is an open dialogue with the local community, including community authorities, throughout the entire chain of the mine's operations-from the identification of the deposit to reclamation of the terrain. The best example of how a well-targeted local policy works is how quickly the mine managed to obtain permission to expand the deposit. In this case, it took only three years, in which many significant changes were made, including the provisions of the resolution establishing the landscape park (lifting the mining ban), but also in local planning documents. Taking into account the complexity of Polish administrative procedures as regards to obtaining mining licenses, this can be called a success, which undoubtedly was contributed to by many factors and which distinguishes the mine from others in Poland that found themselves in similar situations. The process of applying for a licence is difficult and complex and is sometimes burdened with the threat of social protests, which may extend it by many years and because of which a project may end in failure. The example of the CLM shows that it is possible to find optimal solutions in this respect. However, these must not be ad hoc, but rather far-sighted actions, and most importantly taken ahead of the mine's next steps. In this case, the positive image of the company among local stakeholders (the society, but also the community authorities), which it has been building from its very beginnings turned out to be the key to success [81]. Both activities in the scope of minimizing the mine's impact on the environment, and perhaps most importantly, the properly conducted social dialogue contributed to this image. Activities aimed at obtaining social licence to operate (conducted by CLM) determine new standards in this field regarding open-cast mining. Their greatest advantages are regularity, comprehensiveness, strong stakeholder orientation as well as transparency on each step of mining activity. These features distinguish the open-cast mine from others in the region and country.

Author Contributions: Conceptualization, A.K.-N. and A.P.; methodology, A.K.-N.; investigation, A.K.-N. and A.P.; writing —original draft preparation, A.K.-N.; writing—review and editing, A.P.; supervision, A.K.-N.; funding acquisition, A.K.-N. Both authors have read and agreed to the published version of the manuscript.

Funding: This article has been supported by the Polish National Agency for Academic Exchange under Grant No PPI/APM/2019/1/00079/U/001.

Conflicts of Interest: The authors declare no conflict of interest.

\section{References}

1. Witthen, T. Mongolia: Tough Decisions about the World's Oldest Nature Reserve. Available online: https://blogs.worldbank.org/eastasiapacific/mongolia-tough-decisions-about-the-worlds-oldestnature-reserve (accessed on 20 July 2020).

2. Revitalization of Mongolia's Protected Areas through Effective Forest Management of Bogd Khan Uul. Environmental and Social Impact Assessment; World Bank Group: Washington, DC, USA, 2010; pp. 1-194. 
3. Philips, A. Mining and Protected Areas; Finale Report from the Mining, Minerals and Sustainable Development Project (MMSD Project); International Institute for Environment and Development: London, UK, 2001.

4. Lunney, D. A history of a contested ideal: National parks for fauna conservation. Aust. Zool. 2017, 39, 371-396. [CrossRef]

5. Meine, C. Conservation Movement, Historical. In Encyclopedia of Biodiversity, 2nd ed.; Levin, S.A., Ed.; Academic Press: Waltham, MA, USA, 2013; Volume 2, pp. 278-288.

6. Philips, A. Mining, Biodeversity \& Protected Areas. An IUCN Viewpoint; International Institute for Environment and Development: London, UK, 2001.

7. Skowroński, A. Wydarzenia i ludzie początków prawnej ochrony przyrody w Polsce (Events and people of the beginnings of legal environmental protection in Poland). Studia Ecol. Bioethicae 2005, 3, 355-368. (In Polish)

8. Kasztelewicz, Z.; Kozioł, W. Open-Cast Mining Activity in Poland over the Last 50 Years and Development Perspective for the First Half of the 21st Century; AGH UST Bulletin No. 85; Wydawnictwo AGH: Krakow, Poland, 2015; pp. 8-15. (In Polish)

9. Szuflicki, M.; Malon, A.; Tymiński, M. (Eds.) The Balance of Mineral Resources Deposits in Poland as of 31.12.2018; The Polish Geological Institute-National Research Institute: Warsaw, Poland, 2019; pp. 1-492. Available online: http://geoportal.pgi.gov.pl/surowce (accessed on 15 July 2020). (In Polish)

10. Kot-Niewiadomska, A. Possibilities of Open-Cast Mining in Landscape Parks in Poland-Case Study (poster). In Book of Abstracts, Proceedings of 3rd International Conference on the Sustainable Energy and Environmental Development, Krakow, Poland, 16-18 October 2019; Institute of Sustainable Energy: Krakow, Poland, 2019; p. 67.

11. Radwanek-Bak, B. Gospodarka zasobami kopalin skalnych w Karpatach Polskich w warunkach zrównowżonego rozwoju (Management of rock raw material resources in the Polish Carpathians on sustainable development conditioning). Pr. Państwowego Inst. Geol. 2005, CLXXXIII, 123. (In Polish)

12. Radwanek-Bąk, B.; Malata, T. Uwarunkowania środowiskowe zagospodarowania zasobów złóż kopalin skalnych w województwie podkarpackim (Environmental conditioning of the management of the rock mineral deposits in the Podkarpackie Viovodship). Górnictwo Odkryw. 2005, 50, 5-15. (In Polish)

13. Sermet, E. Obszary chronione w granicach Lubelskiego Zagłębia Węglowego-Potencjalna bariera zagospodarowania złóż (Protected areas within the lublin coal basin-Potential barrier of deposits development). Górnictwo Odkryw. 2013, 54, 122-127. (In Polish)

14. Kaźmierczak, U. Dostępność złóż kopalin skalnych w kontekście obszarów prawnie chronionych województwa dolnoślasskiego (Availability of rock raw materials in the context of legally protected areas of the Dolnoslaskie voivodeship). Gospod. Surowcami Miner. 2014, 30, 35-50. (In Polish)

15. Guzik, K.; Kot-Niewiadomska, A. Środowiskowe ograniczenia eksploatacji złóż kamieni blocznych w Sudetach i Górach Świętokrzyskich (Environmental constraints of dimension stones extraction in the Sudetes and the Świętokrzyskie Mountains). Zesz. Nauk. Igsmie Pan 2015, 91, 67-80. (In Polish)

16. Ptak, M. Sieć obszarów Natura 2000 w aspekcie działalności odkrywkowych zakładów górniczych. In Proceedings of the Natural Hazards in Mining, Śleśin, Poland, 4-6 June 2007; pp. 137-151. (In Polish)

17. Kasztelewicz, Z.; Ptak, M. The procedure of Environmental Impact Assessment in opencast mining in the light of new law regulations with particular focus on the specific character of Nature 2000 areas. Gospod. Surowcami Miner. 2009, 25, 153-170.

18. Pietrzyk-Sokulksa, E. Ostoje sieci NATURA 2000 jako element środowiskowych uwarunkowań eksploatacji kopalin (Sites of network Natura 2000 as an environmental conditioning of mineral exploatation). Górnictwo Odkryw. 2009, 50, 16-30. (In Polish)

19. Górecki, J.; Sermet, E. Natura 2000 a społeczna odpowiedzialność górnictwa (NATURA 2000 and mining social responsibility). Zesz. Nauk. Igsmie Pan 2010, 79, 159-168. (In Polish)

20. Ptak, M. Górnictwo odkrywkowe w Polsce oddziaływujące na obszary Natura 2000 w Polsce w liczbach. Górnictwo I Geoinżynieria 2010, 34, 493-503.

21. Radwanek-Bak, B. Konflikty środowiskowe zagospodarowania złóż kopalin eksploatowanych metoda odkrywkowa, zlokalizowanych na obszarach europejskiej sieci Natura 2000—Przykład województwa małopolskiego (Environmental conflicts of open-pit exploitation of mineral deposits inside the european natura 2000 network-A case study from małopolska voivodship). Biul. Państwowego Inst. Geol. 2012, 448, 269-280. (In Polish)

22. Sobczyk, W.; Kowalska, A. Obszary Natura 2000 a działalność górnicza (Natura 2000 Areas Versus Mining Activities). Eduk. Tech. Inform. 2019, 1, 125-131. (In Polish) 
23. Radwanek-Bakk, B.; Nieć, M. Valorization of undeveloped industrial rock deposits in Poland. Resour. Policy 2014, 45, 290-298. [CrossRef]

24. International Project: "Europe's Nature, Regional and Landscapes Parks". Available online: www.europeanparks.org (accessed on 10 June 2020).

25. Act of 16 April 2004 on Nature Conservation (Journal of Laws 2004 No 92, Item 880) as Amended. Available online: https://isap.sejm.gov.pl/isap.nsf/download.xsp/WDU20040920880/U/D20040880Lj.pdf (accessed on 10 June 2020).

26. Act of 27 April 2001 the Environmental Protection Law (Journal of Laws 2001 No 62, Item 627) as Amended (Poland). Available online: https://isap.sejm.gov.pl/isap.nsf/download.xsp/WDU20010620627/U/D20010627Lj. pdf (accessed on 10 June 2020).

27. Act of 24 April 2015 on the Amendment of Certain Acts in Relation to the Strengthening of Landscape Protection Tools (Jurnal of Laws 2015 No 774, Item 1688) as Amended (Poland). Available online: http: //isap.sejm.gov.pl/isap.nsf/download.xsp/WDU20150000774/U/D20150774Lj.pdf (accessed on 10 June 2020).

28. The Act of 3 October 2008 on Sharing Information about the Environment and its Protection, Public Participation in Environmental Protection and Pnvironmental Impact Assessment (Jurnal of Laws 2008 No 199, Item 1227) as Amended (Poland). Available online: http://isap.sejm.gov.pl/isap.nsf/download.xsp/ WDU20081991227/U/D20081227Lj.pdf (accessed on 10 June 2020).

29. Regulation of the Council of Ministers of 10 September 2019 on Projects Likely to Have a Significant Impact on the Environment (Journal of Laws, Item 1839) (Poland). Available online: https://isap.sejm.gov.pl/isap. nsf/download.xsp/WDU20190001839/O/D20191839.pdf (accessed on 10 June 2020).

30. Central Register of Nature Conservation Forms. General Directorate for the Environmental Protection, Poland. Available online: http://crfop.gdos.gov.pl/CRFOP/ (accessed on 20 June 2020).

31. Central Geological Database. Polish Geological Institute-National Research Institute. Available online: http://geoportal.pgi.gov.pl/portal/page/portal/PIGMainExtranet (accessed on 20 June 2020).

32. Pregill, P.; Volkaman, N. Landscapes in History: Design and Planning in the Eastern and Western Traditions, 2nd ed.; John Wiley \& Sons: Hoboken, NJ, USA, 1999; pp. 1-864.

33. Meinecke, H. Hamburg's Prince of Parks. Rotarian 1973, 122, $23-24$.

34. Forst, R.; Scherfose, V. Naturparkmanagement in Deutschland-Qualitätsoffensive Naturparke (Naturschutz und Biologische Vielfalt); Griebsch \& Rochol Druck GmbH: Bonn, Germany, 2016; pp. 1-296.

35. Nature Parks. The German Federal Agency for Nature Conservation (Bundesamt für Naturschutz, BfN). Available online: https://www.bfn.de/en/activities/protected-areas/nature-parks.html (accessed on 21 June 2020).

36. Clarke, R.; Mount, D. Areas of Outstanding Natural Beauty Management Plans-A Guide; The Countryside Agency: Cambridge, UK, 2001; pp. 1-132.

37. Janssen, J. Sustainable development and protected landscapes: The case of the Netherlands. Int. J. Sustain. Dev. World Ecol. 2009, 16, 37-47. [CrossRef]

38. Living Landscape. Europe's Nature, Regional, and Landscape Parks-Model Regions for the Sustainable Development of Rural Areas; Report; Europe's Nature, Regional and Landscape Parks, Europarc Federation, Verband Deutscher Naturparke e. V. (VDN): Bonn, Germany, 2017; pp. 1-174.

39. Blumenthal, V. The Nordic Regional Park Model: A Comparative Case Study of Regional Parks in Norway, Denmark and Iceland. Master's Thesis, Norwegian University of Life Sciences, Ås, Norway, 2017.

40. Summary List of Natural Parks. Executive Environment Agency EEA. Available online: http://eea.government. bg/zpo/en/index_download.jsp (accessed on 15 June 2020).

41. Fifth National Report Convention on Biological Diversity. Federal Ministry on the Environment, Nature Conservation, Building and Nuclear Safety, Germany. 2014. Available online: https://www.cbd.int/doc/ world/de/de-nr-05-en.pdf (accessed on 15 June 2020).

42. Nigel, D.; Shadie, P.; Stolton, S. Guidelines for Applying Protected Area Management Categories Including IUCN WCPA Best Practice Guidance on Recognising Protected Areas and Assigning Management Categories and Governance Types; Monographic Series: Best Practice Protected Area Guidelines Series; IUCN: Gland, Switzerland, 2013; pp. 1-143.

43. International Union for Conservation of Nature (IUCN). Available online: www.iucn.org/ (accessed on 10 June 2020).

44. Parra, C. The Vicissitudes of the French Regional Park Model Illustrated through the Life History of the Morvan. Environ. Hist. 2012, 18, 561-583. [CrossRef] 
45. Report of the Second IUCN World Conservation Congress 4-11 October 2000. Available online: https: //enb.iisd.org/crs/iucn/wcc2/sdvol39num7.html (accessed on 10 June 2020).

46. Guidance for Exploration in Sweden; Svemin: Stockholm, Sweden, 2012.

47. The Act of 16 December 2015 Law on Mining and Geological Exploration (Serbia). Available online: https://www.mre.gov.rs/doc/geologija-rudarstvo/Law\%20on\%20Mining\%20and\%20Geological\% 20Explorations.pdf (accessed on 9 September 2020).

48. Act on Nature Conservation and Landscape Management (Federal Nature Conservation Act-BNatSchG) of 29 July 2009 (Germany). Available online: https://www.bmu.de/en/law/federal-nature-conservation-actbnatschg/ (accessed on 8 September 2020).

49. Questions \& Answers on the Regional Natural Parks of France. 2018. Available online: https://www.parcs-naturels-regionaux.fr/sites/federationpnr/files/document/centre_de_ressources/ pnr_argumentaire_2018_bd.pdf (accessed on 8 September 2020).

50. Carvalho, J.M.; Meira, J.; Marques, C.; Machado, S.; Mergulhão, L.M.; Cancela, J. Sustainable exploitation of mineral resources within an area of the Natura 2000 network. Eur. Geol. J. 2016, 41, 11-15. Available online: https:/eurogeologists.eu/european-geologist-journal-41-sustainable-exploitation-ofmineral-resources-within-an-area-of-the-natura-2000-network/ (accessed on 8 September 2020).

51. Areas of Outstanding Natural Beauty (AONB). Working Together to Support the Rural Economy. Submission in Support of Defra Input to the Rural Economy Growth Review by the National Association for Areas of Outstanding Natural Beauty; The National Association Areas of Outstanding Natural Beauty: Louth, Ireland, 2011.

52. The Nature Protection Act. 2003 (Croatia). Available online: https://www.hah.hr/pdf/Nature_Protection_Act. pdf (accessed on 8 September 2020).

53. European Landcape Convention; European Treaty Series No 176; Council of Europe: Florence, Italy, 2000.

54. Habuda, A. Skuteczność przepisów prawa ochrony przyrody w parkach krajobrazowych i obszarach chronionego krajobrazu (Effectiveness of nature conservation laws in landscape parks and protected landscape areas). In Proceedings of the Nature Conservation in the Hands of Provincial Governments, Supraśl, Poland, 27-29 December 2017. (In Polish)

55. Kuś, B. Działalność gospodarcza na terenie parku krajobrazowego (Business activity in the landscape park). In Działalność Gospodarcza na Obszarach Chronionych; Biskup, R., PyteR, M., Rudnicki, M., Trzewik, J., Eds.; Wydawnictwo KUL: Lublin, Poland, 2014; pp. 275-284. (In Polish)

56. Mastalska-Cetera, B.; Krajewski, P. Plany ochrony parku krajobrazowego jako narzęzie wspomagające zrównoważony rozwój (Landscape park protection plans as a tool to support sustainable development). Probl. Ekol. Kraj. 2014, XXXVII, 147-156. (In Polish)

57. Fogel, A. Parki Krajobrazowe i Obszary Chronionego Krajobrazu-Nowe Rozwiazania Prawne (Landscape Parks and Protected Landscape Areas-New Legal Solutions); Institute of Spatial Planning and Housing: Warsaw, Poland, 2016; pp. 103-119. (In Polish)

58. Kotońska, M.; Broda, M.; Zawartka, J. Czy parki Krajobrazowe Chronia Krajobraz? (Do Landscape Parks Protect the Landscape?); General Directorate for Environmental Protection: Warsaw, Poland, 2012. Available online: http://www.gdos.gov.pl/files/artykuly/5456/Bozena_Kotonska_prezentacja.pdf (accessed on 20 June 2020). (In Polish)

59. Kozłowski, S. Ochrona Krajobrazu, Poradnik Ochrony Przyrody (Landscape Protection. Nature Conservation Guide); Nature Conservation League: Warsaw, Poland, 1980.

60. Żarska, B. Ochrona struktury i funkcjonowania krajobrazów szczególnie cennych przyrodniczo (Protection of the structure and of functioning of landscapes particularly valuable for the nature). Probl. Ekol. Kraj. 2008, XXI, 45-60. (In Polish)

61. Gacka-Grzesikiewicz, E. Ekologiczne problemy tworzenia nowych typów obszarów chronionych jako formy ochrony środowiska (Ecological problems of creating new types of protected areas as forms of environmental protection). Wiadomości Ekol. 1976, 1, 3-25. (In Polish)

62. Denisiuk, Z. Parki Krajobrazowe na tle Systemu Obszarów Chronionych w Polsce (Landscape Parks as Part of the System of Protected Areas in Poland); Institute of Nature Conservation, PAS: Kraków, Poland, 2004; pp. 79-103. (In Polish)

63. Kistowski, M. The prospects for landscape conservation in Poland with special attention to landscape parks. Przeglad Przyr. 2012, XXIII, 30-45.

64. Central Statistical Office. Local Data Bank. Available online: https://bdl.stat.gov.pl/BDL/star (accessed on 25 April 2020).

65. Parki Krajobrazowe (Landscape Parks). Available online: www.parkikrajobrazowe.pl (accessed on 25 April 2020). 
66. Chmielewska, K. Park Krajobrazowy Jako Forma Ograniczenia Prawa Własności (A Landscape Park as a Form of Limitation of Property Rights). 2016. Available online: http://akademia.e-prawnik.pl/porady/ artykuly-3/park-krajobrazowy-jako-forma-ograniczenia-prawa-wlasnosci.html\#sdfootnote6sym (accessed on 25 April 2020). (In Polish)

67. Lipiński, A. Roboty geologiczne i wydobywanie kopalin na obszarach chronionych. Niektóre uwarunkowania prawne (Geological works and mineral extraction in protected areas. Selected legal conditions). In Dziatalność Gospodarcza na Obszarach Chronionych; Biskup, R., PyteR, M., Rudnicki, M., Trzewik, J., Eds.; Wydawnictwo KUL: Lublin, Poland, 2014; pp. 199-218.

68. Badera, J. Konflikty społeczne na tle środowiskowym związane z udostępnianiem złóż kopalin w Polsce (Social conflicts on the environmental background related to the opening of mineral deposits in Poland). Gospod. Surowcami Miner. 2010, 26, 105-125, (In Polish with English abstract).

69. Badera, J. Geneza konfliktów społeczno-środowiskowych związanych z górnictwem (Genesis of socio-environmental conflicts related to mining). Górnictwo Odkryw. 2018, 59, 28-30. (In Polish)

70. The 1994 Oslo Protocol on Further Reduction of Sulphur Emissions (II Sulphur Protocol). Available online: https: //www.unece.org/fileadmin/DAM/env/lrtap/full\%20text/1994.Sulphur.e.pdf (accessed on 24 June 2020). (In Polish)

71. Ratajczak, T. Sorbenty Mineralne-Perspektywiczny Temat w Polskiej Gospodarce (Mineral Sorbents-A Prospective Topic in the Polish Economy). 2019. Available online: http://surowce-naturalne.pl/sorbentymineralne-perspektywiczny-temat-w-polskiej-gospodarce/ (accessed on 25 June 2020). (In Polish)

72. Galos, K.; Szlugaj, J.; Burkowicz, A. Źródła sorbentów wapiennych do odsiarczania spalin w Polsce w kontekście potrzeb krajowej energetyki (Sources of lime sorbents for flue gas desulphurisation in Poland in the context of national power sector's needs). Polityka Energetyczna 2016, 19, 149-170. (In Polish)

73. Stowarzyszenie Przemysłu Wapienniczego (Association of Lime Industry). Available online: http://www. wapno-info.pl/ (accessed on 24 June 2020).

74. Kotowski, C.Z.; Ratajczak, T. Karbońskie wapienie z Czatkowic-Ich charakterystyka surowcowa a możliwości wykorzystania (Carboniferous limestone from "Czatkowice" - Their raw material characteristics and possibilities of use). Górnictwo Geoinżynieria 2010, 34, 339-348.

75. Kotowski, C.z.; Kubajak, P. (Eds.) Kopalnia Wapienia "Czatkowice" "w Krzeszowicach (The "Czatkowice" Limestone Mine in Krzeszowice); Grapfa Studio: Kraków, Poland, 2019; pp. 1-158. (In Polish)

76. Kopalnia Wapienia "Czatkowice" ("Czatkowice" Limestone Mine). Available online: www.|T1 textquotedblleftCzatkowice\T1\textquotedblright.pl (accessed on 20 June 2020).

77. Resolution No XV/247/11 of the Lesser Poland Province Assembly regarding the Krakow Valley Landscape Park. Available online: https://bip.malopolska.pl/zpkwmalopolskiego,m,4233,rozporzadzenia-i-uchwaly. html (accessed on 24 April 2020).

78. Kot-Niewiadomska, A.; Seta, T. Zrównoważony proces koncesyjny a planowanie przestrzenne—udział Kopalni Wapienia "Czatkowice" w międzynarodowym projekcie MinLand (Sustainable licence process and spatial planning-participation of the "Czatkowice" Limestone Mine in the international MinLand project). In Proceedings of the School of Open-cast Mining, Kielce, Poland, 9-11 December 2019. (In Polish)

79. The Decision of Environmental Conditions for Extending of Exploitation of Limestone Deposit towards Paczóltowice Village; Mayor of Krzeszowice Commune: Krzeszowice, Poland, 2014.

80. Luodes, N.; Arvidsson, R.; WP3 task 3.2Working Group. Deliverable: D3.2 Case studies summary. MinLand Project-Mineral resources in sustainable land-use planning. Case Studies of Land Use Planning in Exploration and Mining. 2019. Available online: https://www.minland.eu/wp-content/uploads/MinLand_D3.2-SummaryCases.pdf (accessed on 10 July 2020).

81. Nowak-Far, A. Prawno-międzynarodowe uwarunkowania ochrony krajobrazu w Unii Europejskiej i w jej państwach członkowskich (Low and International landscape protection conditions in the European Union and its Member States). Kwart. Studia Polityki Publicznej 2017, 1, 25-44, (In Polish with English abstract). [CrossRef]

Publisher's Note: MDPI stays neutral with regard to jurisdictional claims in published maps and institutional affiliations. 